\title{
Frazeologija v prozi Janka Kersnika
}

\author{
Jurij Rojs
}

IZVLEČEK: V̌̌lanku avtor obravnava frazeologijo v prozi slovenskega pisatelja Janka Kersnika. K tej pritegne tudi frazeme v Kersnikovih pismih. V̌̌iršo frazeološko obravnavo vključuje krilatice, pregovore in reke ter citate. Obsežno frazeološko gradivo razvršča glede na različne tipe frazeoloških struktur. Med temi prevladujeta dva tipa frazemov: frazemi s strukturo samostalnik + glagol ter pridevnik $+s a-$ mostalnik. Izčrpni pregled frazeološkega gradiva konča s statističnim pregledom frazemov. Iz tega je razvidno, da je uporaba frazeologije zelo močna sestavina Kersnikovega pisateljskega ustvarjanja.

\section{Idioms in the Prose of Janko Kersnik}

ABSTRACT: This article examines idioms in the prose of the Slovenian writer Janko Kersnik as well as idioms in Kersnik's letters. The broader idiomatic examination includes stock quotations, proverbs, sayings, and quotes. The extensive idiomatic material is organized by various types of idiomatic structures. Two types of idioms predominate among these: noun + verb idioms and adjective + noun idioms. This exhaustive overview of idiomatic material concludes with a statistical overview of idioms. This makes it clear that the use of idioms is a very strong component of Kersnik's literary creation.

Teoretične poglede na frazeologijo sem podal v razpravi Frazeologija v prozi Josipa Jurčiča. Izhajam iz lastnega pojmovanja frazeologije, ki sem ga dobil pri študiju frazeologije na Filološki fakulteti v S-Peterburgu, kjer sem stažiral v študijskem letu 1969 /70 in v času magistrskega in doktorskega študija na Filozofski fakulteti Vseučilišča v Zagrebu ter v času izrednega študija na Institutu ruskega jezika v Moskvi. Za svetovanje pri nekaterih frazemih se lepo zahvaljujem akad. prof. dr. Jožetu Toporišiču in prof. dr. Antonu Stresu, prav tako tudi Univerzitetni knjižnici v Mariboru, ki mi je za dalj časa posodila Zbrana dela Janka Kersnika. Kersnikova proza sodi na sam vrh slovenskega poetičnega realizma. A. Slodnjak trdi, da je J. Kersnik dosegel višek poetičnega realizma z Jaro gospodo, akad. Boris Paternu pa meni, da predstavlja vrh povest Očetov greh - tudi jaz menim tako. Radovednost, kakšna je frazeologija pri tem imenitnem pisatelju, me je gnala k raziskovanju frazeološke besede. H Kersnikovi prozi sem dodal še šaloigro (enodejanko) Berite 
Novice, Kersnikove poezije se ne dotikam. ${ }^{1}$ V Kersnikovi prozi je največ frazemov $\mathrm{s}$ samostalniško jedrno besedo in glagolsko komponento. To so tako imenovani samostalniški (imenski) frazemi, ki so skupaj z glagolskimi najštevilčnejši v Kersnikovi frazeologiji. Ravno samostalnik in glagol sta središče frazeoloških tvorb. Samostalnik je nosilec osnovnih semantičnih in gramatičnih lastnosti. Samostalnik ohrani pomen predmetnosti in sklanjatev. Frazeoloških enot, ki bi bile soodnosne s števniki, skorajda ni. Števniki so omejeni po količini besed, ne dopuščajo sinonimov. Besede, kot so: dvojka, trojka, dvanajsterica... ne sodijo k števnikom, marveč $\mathrm{k}$ samostalnikom. Mnoge UBZ imajo funkcijo prenesenih frazemov za izražanje količinskih pojmov, kot npr.: poldrugi, peti križ...K števniškim frazemom tudi ne prištevam UBZ, kot so: prvi med enakimi, od štirih do petih, ker dajejo neko kakovostno ali časovno oznako. Zaimenskih FE ni veliko. Podobno kot števniki, so tudi zaimki omejeni. Izražajo funkcijo navodil (rus. ukazanij), ne označujejo pa predmetov ali oznake. Pri samostalniških frazemih je treba vedeti, da $v$ ta razdelek ne prištevam vedno frazemov na osnovi tega, če je njihova jedrna beseda samostalnik. Odločujoča je njihova semantika in osnovne gramatične funkcije ter njihova vloga $v$ stavku. K substantivnim FE prištevamo tiste, pri katerih je jedrna beseda samostalnik, ki ohrani svoj predmetni pomen in sposobnost, da se sklanja. V svojem magistrskem delu sem te FE imenoval imenske. V stavku imajo skladenjsko funkcijo osebka, povedka in predmeta. Glede na svojo leksikalno-semantično strukturo so zelo različni, prav tako pa tudi glede na označevanje realnosti. Zato je njihova klasifikacija zelo zahtevna in še nedodelana. Ruski frazeolog prof. A. P. Mordvilko $\mathrm{o}^{2}$ predlaga naslednji vrstni red obravnave teh frazemov: a) frazemi $\mathrm{s}$ spremenjenim pomenom jedrnega samostalnika in b) frazemi, pri katerih ohrani samostalniška jedrna beseda svoj neposredni pomen.Morfološka struktura teh frazemov je preprosta. Večinoma gre za vezavo (nem. die Verbindung, rus. sočetanie) jedrnega samostalnika in ujemajočega se z njim v spolu, sklonu in številu pridevnika

1 Frazeološko gradivo jemljem iz virov:

a) Janko Kersnik: Zbrano delo, I. knjiga (Na Žerinjah: NŽ; Lutrski ljudje: LL; Gospod Janez: GJ; Leposlovni podlistki: LP), DZS, Ljubljana 1968.

b) Janko Kersnik: Zbrano delo II. knjiga (Ciklamen: C; Agitator: A; Humoreske: H), DZS, Ljubljana 1965.

c) Janko Kersnik: ZD III. knjiga (Kmetske slike: KS; Testament: T; Rošlin in Vrjanko: RV; Jara gospoda: JG), DZS, Ljubljana 1986.

d) Janko Kersnik: ZD IV. knjiga (Povesti za ljudstvo: PZL; Očetov greh: OG; Berite Novice: BN; Pesmi), DZS, Ljubljana 1951.

e) Janko Kersnik: ZD V. knjiga (Podlistki: PO; Postna premišljevanja: PPr; Članki: Č; Ocene: O; Dodatek; D), DZS, Ljubljana 1952,

f) Janko Kersnik : ZD VI. knjiga (Pisma: Pismo; Dodatek: D), DZS, Ljubljana 1984.

g) Janko Kersnik: Izbrano delo I. knjiga (Iz raztresenih listov: IRL; Kmetske slike: KS; Humoreske: H; Jara gospoda: JG; Pesmi v prozi: PVP), MK, Ljubljana 1974

h) Janko Kersnik: Izbrano delo II. knjiga (Iz raztresenih listov; IRL; Ciklamen: C; Agitator: A; Podlistki: PO; Nedeljska pisma: NP; Popotna pisma: PP; S slavnostnim vlakom v Kočevje: SSVVK), MK, Ljubljana 1974.

i) Josip Jurčič: Izbrano delo IV. knjiga (Rokovnjači: R), MK, Ljubljana 1974.

2 A. P. Mordvilko, Očerki po russkoj frazeologii, Moskva 1964. 
(npr.: črne oči, ostra beseda). Odvisna komponenta imenskega frazema je lahko druga beseda, kot npr: a) svojilni pridevnik: »Damoklejev meč«/K, ZD V, 156 /; b) samostalnik v rodilniku: »cvet inteligence«/K, ZD II, 248 / in c) samostalnik v drugih odvisnih sklonih (navadno s predlogom): »za pičico«/K, ZD V, 377/. Redkeje predstavlja imenski frazem zvezo dveh samostalnikov (ali substantiviranih pridevnikov), združeno s členicama »ni« ali »ne«: »ni duha ni sluha«/K, ZD I, 35 /, »ne živ ne mrtev«/K, ID IV, 38 /. Prav tako so redki imenski frazemi, ki predstavljajo zvezo števnika ali zaimka s samostalnikom, npr.: »deveta skrb«/K, ZD IV, 186 /, »naše gore list«/K, ZD V, 286 /.

\section{Frazemi s strukuro samostalnik kot jedrna beseda in glagolska komponenta}

Teh frazemov sem našel tristo sedemdeset in jih navajam po abecednem redu jedrnih besed. ${ }^{3}$ »...Miklavž sam tudi ni črhnil besede... «/K, T, ZD III, 84 /. »Sedaj sem vezan - v mestu sem dal besedo »/K, Hrast, A, ID II, 271 /. »...naposled obrne Blažek besedo... «/K, H, ZD II, 154 /. »Vesel glas od vrat...odrezal mu je besedo « / K, C, ID II, 29 /. Včasih se jedrna beseda nanaša na nadredni in podredni stavek, kot npr.«...požrl (je) drugo besedo, ki mu je bila na jeziku /K, RV, ZD III, 169 /. »Srp je prišel prvi do besede...«/K, H, ZD II, 256. »Župnik je segel $v$ besedo...« /K, ID I, 167 /. »...segne doktor sodniku $v$ besedo «/K, RV, ZD III, 164 /. »Doktor Božan mu je vtem vzel besedo... «/K, RV, ZD III, 164 /. »On ne zine besede... «/K, OG, ZD IV, 96 /. Enako FE še imamo v noveli Gospod Janez /K, ZD I, 205 /.

»On se je šel z bikom bost /K, neki kmet, R, ID IV, 73 /. »Blaž, če rokovnjači zvedo, da si ti prvi šel bob iz kropa pobirat...«/K, Urh, R, ID IV, 90 /. »Božje ga je metalo...2 /KS, ID I, 79 /. »Božje ga je vrglo«/K, KS, ID I, 79 /. »...starešina hodi iz hiše tja uganjat svoje burke...«/K, OG, ZD IV, 116 /. »Oreh si je pri tem vil svojo cigareto...«/K, H, ZD II, 262 /. »...na čelu je jahal lep lajtnant«/K, LP, ZD I, 248 /.

Frazeološki somatizem srečamo v stavku: »Nagubančil je čelo ter segel po kozarcu...«/K, GJ, ZD I, 191 /. Dva različna frazema sta v odvisnem stavku: »Gospod Tomaž...ve, da svet ne stoji na suhi črki svetega pisma...«/K, RV, ZD III, 261 /. Tudi Vid ne more z besedo na dan...«/K, PZL, ZD IV, 61 /. Jedrna beseda dan še je v devetih frazemih iz različnih del, npr.:: »... a volka samega ni bilo na dan «/K, C, ID II, 55 - enak frazem še je v Humoreskah /K, ZD II, 55 /. Različne glagolske komponente imajo frazemi : »...pa bojim se, da se prekmalu pokaže na dan « /K, A, ID II, 239 /. FE z različno glavno komponento je izražena v naslednjih dveh frazemih: »...Repincljevi dnevi so šteti«/K, H, ZD II, 257 in »Tako so tekli dnevi...«/K, H, ZD II, 262 /. SP 1962 ima naveden frazem, ki ga zapiše J. Kersnik v odvisnem stavku: ॥Vi ne veste, da včasih delo ne gre tako od rok, kakor bi vsak hotel«/K, Manica, BN, ZD IV, 194 /.

Samo enkrat sem zasledil UBZ: »Tisti grof Sori ni prišel samo dolgčas proda-

3 Janez Kersnik in njegov čas, Kranj 1997, Viktor Majdič, Kersnikov pogled na jezik. 
jat...«/K, Gernau, NŽ, ZD I, 73 /. Prav tako sem posamično srečal frazem: »...jaz ji bom moral doto šteti«/K, Topolščak, T, ZD III, 93 /. Z jedrno besedo duša ima J. Kersnik dva frazema: »Tri dni pozneje je ponesrečeni izdihnil svojo dušo«/K, KS, ID I, 35 /. Povsem drug pomen ima FE: »Poleg tega pa duše paseš! «/K, GJ, ZD I, 190 / - tj. opravlja duhovniško službo. Petkrat sem srečal jedrno besedo dušek: je dal dušek /K, H, ZD II, 251 /, dati duška /K, RV, ZD III, 186 / - enak frazem je v O /K, ZD V, 292 /; drugačna glagolska komponenta je v stavku: »Ko se je Pavel vrnil $\mathrm{k}$ mizi, izpraznil je $v$ dušku svoj kozarec...«/K, RV, 211 /. Jedrna beseda glas ima več različnih realizacij: »Marko joka na ves glas «/K, PZL, ZD IV, 51 /. »...kričal je na ves glas «/K, Tomaž, T, ZD III, 112 / -enaka FE še je v povesti Jara gospoda /K, ID I, 183 /. »...Štupa je sam loputil na ves glas...! /K, RV, ZD III, 225 /. Ta FE se še uporablja dvakrat s komponento trobiti, vzklikniti in zasmejati se /K, PO, ZD V, 211; /K, OG, ZD IV, 162 / in v PZL /K, ZD IV, 51 - naveden je tudi v JG /K, ID I, 187 /. Frazeološki somatizem z jedrno besedo glava sem opazil enajstkrat, npr.: po glavi hodi /K, odvetnik, A, ID II, 298 /; ni hotelo $v$ glavo /PZL, ZD IV, 37 /. To FE še pisatelj podkrepi s samostalniško komponento: ni šla v glavo in razum $/ \mathrm{K}, \mathrm{PZL}$, ZD IV, 74 /. »...potlej bode šele glavo pokonci nosil...«/K, neki kmet, R, ID IV, 71 $/ 72$ /. Naslednja dva stavka imata imenski in glagolski frazem: »Hrastu je zavrelo po vseh udih, pa vendar je stal tako lesen in nem pred njo. Še glavo je povesil«/K, C, ID II, 142 \%. Zadnji frazem imamo naveden trikrat v romanu NŽ /K, ZD I, 91, 91 in 120 /. Le enkrat sem opazil FE: »...prišla (je) kaka burka $v$ glavo...«/K, LP, ZD I, 233 /. S to jedrno besedo se še uporabljajo komponente stoje /K, PO, ZD V, 44 /, šinila, šinilo, ubila, ubijati, vzdigniti in hoteti /K, RV, ZD III, 248; T, ZD III, 129; Llj, ZD I, 163; RV, ZD III, 246, 259; PO, ZD V,110; GJ, ZD I, 206 in RV, ZD III, 224 /. »Povše gleda zavidno vse po strani...«/K, SSVVK, ZD V, 221 /; taisti frazem se ponovi na naslednji strani. J. Kersnik piše ločeno predlog in prislov, SP 2001 piše skupaj, tj. postrani.

»Kje ste bili včeraj?« zavrnila je ona, da preseče govor na drug predmet«/K, RV, ZD III, 166 /. »Drugim pa ne gledam $v$ grlo« /K, Stupa, RV, ZD III, 213 /. »Jaz pravim, da bo ona hlače nosila...«/K, krčmarica, C, ID II, 168 /. Le enkrat sem zasledil FE: »Še v ljubljanski kazini se mu bodo za hrbtom smejali«/K, PO, ZD V, 101 /. »...za hrbtom pa so ga rešetali in skozi zobe vlekli«/K, A, ID II, 196 /. Nejevoljo izraža FE: »Jeza, grozna jeza ga tare«/K, PZL, ZD IV, 59 /.

Dvanajstkrat je realiziran frazem $\mathrm{z}$ jedrno besedo jezik z različnimi glagolskimi komponentami, kot npr.: »jezike brusijo /K, KS, ID I, 58 /, »na jeziku imel« /K, Tine, NŽ, ZD I, 15 /, /K, T, ZD III, 141, RV, ZD III, 170 /; »se je odvezal jezik“ /K, H, ZD III, 267 /, »se je omajal jezik« /K, KS, ID I, 71 /; »se je jezik opotekal« /K, T, ZD III, 124 /; »je prišla ...beseda na jezik« /K, RV, ZD III, 252 /; »pride na jezik«/K, PZLj, ZD IV, 56 /; »v jezik vgriznil«/K, T, ZD III, 134 /; »beseda mu ni hotela raz jezik«/K, RV, ZD III, 192 /; »mu je zavezal jezik«/K, T, ZD III, 122 /; »naj jezik za zobmi drži«/K, NŽ, ZD I, 103 /.

Posamezno srečamo frazeme: »...malo let je minilo, odkar je pri nas pognalo narodno življenje svoje drobne kali...«/K, LP, ZD I, 261 /V SSKJ je navedena FE: kamen se mu je odvalil od srca, pisatelj J. Kersnik jo po svoje interpretira: »...ka-

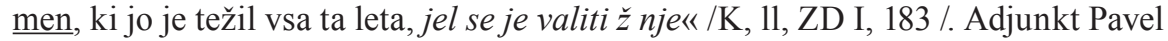


vpraša: »Ali vas je kap zadela?«/K, JG, ID I, 190 /. »Kjer pa štirje igrajo karte...« /K, H, ZD II, 249 /. »...zato ni je' na kol obesil'... /K, PO, ZD V, 125 /; »(je) obesil študiranje na kol« - komponento je postavil J. Kersnik pred narekovaj /K, PO, ID II, 312 - enak frazem še je v PO, ZD V, 97. »Če mu še ne manjka koleščka v glavi« /K, Franca, LP, ZD I, 234 / - pog., šalj. Naslednja dva frazema imata sicer enako jedrno besedo, pomen pa je različen: »...vsako leto je vedela nekaj besed več in uporabljala jih je na pravem koncu«/K, C, ID II, 112 /. »Sklenil je stvari priti do konca «/K, A, ID II, 260 /. V narekovaj postavi Kersnik frazem: »V dobrem tednu je bil Rokec že res kar na konju«...«/K, H, ZD II, 284 - FE se redko uporablja, njen antonim je: biti na psu.»Ej, gospod Luka, nocoj sva pa - med koprive padla!«/K, Frančišek, JG, ID I, 168 /. O gospici G. Nigrinovi pa moremo in moramo le povedati, da ni bila nikakor kos tej veliki nalogi...«/K, DO, ZD V, 412 / - ekspr. Dvakrat nahajamo frazem: kozolce preobračevati /K, Bole, C, ID II, 137 / - enakega imamo v avtorskem jeziku v PO, ZD V, 188. Po SP: kozolce prevračati.

Več FE ima jedrno besedo koža, le-ta je je lahko debela /K, DO, ZD V, 7 /, trda /K, JG, ID I, 188 /, zdrava /K, R, ID IV, 166 /; glagolski komponenti pa sta dreti /K, PO, ZD V, 7 / in poskočiti /K, J, ID IV, 55 / - SP: iz kože skočiti. Jezen Pavel iz JG reče: »Čakajte, sam ga vprašam, potem pa pridemo stvari na kraj «/K, ID I, 200 \%. V naslednjem zloženem stavku imamo dva frazema: »Pa Pavel je začel sam pripovedovati vse od kraja do konca, kar mu je težilo dušo« /K, RV, ZD III, 256 / - tu imamo predložnosklonsko obliko dveh samostalnikov in vezavo $\mathrm{z}$ drugačno jedrno besedo.

Kar deset frazemov ima jedrno besedo kri: »...le ena želja jo je navdajala in gnala ji kri v razburjeno lice...«/K, LL, ZD I, 178 /. Kri sili v lice /K, GJ, ZD I, 199 / - enaki FE še imamo v avtorskem jeziku, v PZL, ZD IV, 39 in v RV, ZD III, 225. »Topolščaku je kri silila v glavo...«/ZD III, 86 in 129 /. Sinonimno komponento za lice srečamo v FE: »In to spoznanje gnalo mu je skoro zopet kri v obraz«/K, LL, ZD I, 151 \% Z različnimi glagolskimi komponentami imamo strukturno enake frazeme: »vzkipi mu zopet kri«/K, JG, ID I, 213 /; »kri je zalila obraz«/K, LL, ZD I, 147 /. Kot zadnji tovrstni frazem je: »In vendar smo le mi tisti, ki bi dali vse - vse, zadnjo kapljo krvi...«/K, mladi dijak, RV, ZD III, 172 /.

Za pogovorni jezik je značilen frazem: »Občine so poleg vseh teh novih klatežev imele svoje velike križe tudi s starimi, od nekdaj neiztrebljenimi četami zlih ljudi...«/Jurčič, R, ID IV, 15 \% Evfemistični je frazem: »...ti pojdeš za očetom $v$ krtovo deželo!«/Jurčič, R, ID IV, 41 /. »Kar tako mačka v vreči kupiti...«/K, Rokec, H, ZD II, 285 / - ekspr., SSKJ navaja komponento žakelj. »...ne bom vam slikal groznih, lase kvišku privzdigujočih dogodkov...«/K, PO, ZD V, 93 / - pog. ...vsi pa so edini v tem, da se jim ježe lasje...«/K, OG, ZD IV, 113 / - ekspr. »...nadepolnost Jaroslava Podgolovskega je visela na lasu... «/K, LP, ZD I, 239 / - ekspr. » Že

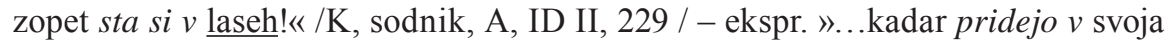
leta...«/K, PO, ZD V, 86 / »...mladi mož je ležal vznak na postelji...«/K, RV, ZD III, 260 / - ekspr. »Pa pustimo mu veselje, bog, da bi že spal na svojih lovorih «/K, PO, ZD V, 19 / - vznes.

Na življenje v gledališču kaže UBZ: »...Vinko, ti vendar ne bodeš igral role tragičnega junaka« /K, Rogulin, NŽ, ZD I, 71 /. »...nobeden ni našel milosti pred 
njegovim očesom » /K; H, ZD II, 249 / - ekspr. V pogovornem in knjižnem jeziku je v rabi FE: »Pusti mojo Marijano, naj v miru počiva!«/K, Urh, R, ID IV, 82 /. Večkrat se ujemata frazema pri J. Jurčiču in J. Kersniku, npr.: »Tončku pa, rokovnjaškemu pomočniku pri konjskih tatvinah, zdaj niti na misel ni prišlo«/Jurčič, R, ID IV, 33 /. »...ni nikomur prišlo na misel... «/K, JG, ID 04 / - ekspr. SSKJ navaja BZ: zatopiti se v misli - ekspr. Kersnik pa zapiše: »Doktor pa je $v$ čudne misli utopljen nem sedel poleg nje... /K, RV, ZD III, 161 /. Brez stilno-plastnega kvalifikatorja je frazem: »Pa druge misli so mu šinile v glavo«/K, LL, ZD I, 177 /. Tako še: »Saj ji še $v$ mislih ne more biti...«/K, Pavel, RV, ZD III, 159 /. Ekspresiven je frazem, ki ga da sam pisatelj v narekovaj. »...priznal (je), da ga ' luna trka' «/K, Corpus juris, LP, ZD I, 235 \%.

Medstilni so naslednji frazemi: »Mesec je pokazal svoj prvi krajec«/K, RV, ZD III, 184 /. »...človek pušča druge v miru...«/K, GJ, ZD I, 218 /. »...prišlo mu je na misel« /K, NŽ, ZD I, 110 /. Šaljivost izraža frazem: »...ta jih bode učil kozjih molitvic, ne pa božjih!«/K, JG, ID I, 168 /. »Nekaj čudnega mu je rojilo po možganih «/K, PZL, ZD IV, 47 / - ekspr. »...le-ta pa išče konca prave niti...«/K, OG, ZD IV, 122 / - pog.

V pomenu 'ozdraviti' je zapisana UBZ: »...mi ga spravimo na noge! « /K, zdravnik, T, ZD III, 83 \%. »...klobuk predse moleč (je) stopal lahkih nog proti zrcalu«/K, C, ID II, 17 /. V pomenu 'urno kaj storiti' je frazem: » - a sedaj bo treba na noge stopiti! /K, Hrast, A, ID II, 268 /. »Tega pa ne, da bi se ti iz mene norca delala!«/K, Marjana, BN, ZD IV, 174 / - pog. Sodnik reče: »Kdo pa vas ima za norca? /K, T, ZD III, 140 /.

Jedrna beseda nos je v osmih frazemih: »imam tak dober nos «/Jurčič, Blaž, R, ID IV, 20 /, enako /K, ZD I, 63 /. »... bode še bolj vihal svoj nos! «/K, neki kmet, JG, ID I, 175 /; »...bodeta nosove vihala...«/K, Bole, C, ID II, 137 /. Pomen prevaranosti je v FE: »...vodi jih za nos «/K, Babtista, PO, ZD V, 64 / - enako K, R, ID IV, 176. Pogovorna sta frazema: »Kaj pa vtikaš nos $v$...«/K, Molek, H, ID I, 103 / in : »...tendence so jim bile zapisane na nosu in na palcu... / /K, PO, ZD V, 116/117 / - v tem primeru gre za klimaks jedrne besede.

Resnični svet okrog sebe zaznavajo Kersnik in njegovi junaki še največ z očmi. Ravno oko je izmed vseh frazeoloških somatizmov najpogosteje prisotno, npr.: »... je dvignila oči... «/ K, LL, ZD I, 140 /. »je dvignil oči« /K, H, ZD II, 256 /. »... ona ni dvignila očesa...«/K, C, ID II, 158 /. »...se mu bodo oči odprle«/K, PO. ZD V, 183 /. »... z odprtimi očmi (je) sanjal«/K, RV, ZD III, 253 / - ta frazem navaja SSKJ, srečamo ga tudi v Jurčičevih Rokovnjačih: »Ali žena je toliko odprte oči imela..." /ID IV, 35 /. Nekakšno zadrego izraža FE: »...toda on je povesil oči«/K, RV, ZD III, 185 /. Tako tudi: »...(ona)...je z a r d e v š a povesila oči...«/K, GJ, ZD I, 203 /. Vran zatrjuje: »...ne bom povešal oči«/K, GJ, ZD I, 210 /. V slovenščini se pogosto uporablja FE dobiti pred oči« /K, H, ZD II, 248 /. Pri začudenju: »...razširil je oči «/K, T, ZD III, 97 /. V Ciklamnu in Jari gospodi »se srečujejo z očmi« /K, ID II, 138; ID I, 206 - ta FE je v avtorskem jeziku. Besedo, stoječo pred FE, J. Kersnik pogosto akcentuira: »Odgovoril ni, nego le vprašuje uprl oči v gospo« /K, RV, ZD III, 243 /. Glagolsko komponento postavi v nedovršni vid: »...in upiral (je) svoje oči v krasno postavo grofice...«/K, NŽ, ZD I, 51 /. Omenjena glagolska komponenta 
se uporablja v različnih spregatvenih oblikah, npr.: »upira oči «/K, OG, ZD IV, 94 /. Glagolska komponenta se uporablja še v pretekliku: »...pogledal ni sina, nego oči upiral v tla«/K, RV, ZD III, 205 /. Isti frazem je v noveli Gospod Janez /K, ZD I, 188 /. Križanje dveh frazemov je v stavku: »Svojih črnih oči ne bi upiral sleherni dan...«/K, Od Mure, ZD V, 71 /. V Leposlovnih podlistkih imamo glagolsko komponento v mn.: »...so upirali osorno svoje oči «/K, ZD I, 251 /, Jedrno besedo oko v ed. zatisniti + oko v im. ali rod. zapiše pisatelj večkrat /K, C, ID II, 110; RV, ZD III, 149; KS, ID I, 42; ID I, 91 \%. Zavoljo razburjenosti : » ...(se mu je)...zmračilo pred očmi «/K, GJ, ZD I, 221 \%

V povesti OG ima Lenka nezakonsko dete: »Sedaj pa je bil ogenj v strehi...« /K, ZD IV, $106 /$.

Vzneseno učinkuje FE v stavku: »Knjižica..., ki jo je položil na oltar domovini...«/K, O (Godec), ZD V, 294 /. »... kakor bi vsa stvar ne bila vredna piškavega oreha...«/K, JG, ID I, 205 / - ekspr. »...otrobe vezati...«/K, PO, ZD V, 39 / - ekspr. »...gospod Blaž pase ovčice...«/K, notar, JG, ID I, 157 / - rel. »Oh, kaj bom iskal ovinkov! « /K, koncipist, A, ID II, 253 / - pog., pomeni pa: nekaj naravnost povedati. V OG je ekspr. FE: »... ako bi se mi pajčevine delale po želodcu!«/K, ZD IV, 125 / - to UBZ navaja tudi SSKJ. Menim, da je tudi frazem BZ: »...prijel je gospod Rus Zgago pod pazduho...«/K, H, ZD II, 264 /. V RV imamo drugačno gl. komponento: »Ivo je vzel sina pod pazduho...«/K, ZD III, 152 /. Avtorski je frazem: »...danes pa prav po klepetuljsko brusim - ne jezika, temveč pero po papirju...« /K, PO, ZD, V, 16 /.

Omeniti velja, da ima Kersnik inverziran besedni red. Nekako poetično zveni frazem: »...jame pripovedovati pesem, katero je bil skoval...«/K, LP, ZD I, 237 /. Naj še omenim, da je raba predpreteklega časa pri Kersniku dokaj pogosta. V noveli GJ imamo na 210. strani glagolsko komponento v nedovršnem vidu: je stiskal pesti in na 211. str. je ista gl. komponenta v dovršniku: »Tu so se mu zopet krčevito stisnile pesti« /ZD I /. Drug pomen je v frazemu: »...(Lovrenčiča)...je kar sam na svojo pest povabil«/K, PO, ID II, 322 / - frazem sodi na pogovorno raven. »Piti zna, piti in pete brusiti...!«/K, Ožbolt, T, ZD III, 101 / - ekspr. V Jurčičevem zapisu Rokovnjačev je frazem: »...pete odnesti«/ID IV, 15 /. Junak Blaž iz Rokovnjačev izreče vulgarni frazem: »...kadar pete stegneš«/Jurčič, ID IV, 25 / - tj. kadar boš umrl.

Kersnikov jezik je s frazeološkega vidika zelo bogat in čeprav je izhajal iz »višjih slojev«, kjer so doma govorili nemško - o tem pričajo v nemščini napisana pisma materi in očetu, je imel svoj pogled na slovenski jezik ${ }^{4}$. Kersnik se je boril proti avstro-ogerskemu pritisku na Slovence. V članku Barbarizem v slovenskih krajevnih imenih pravi: »Vsak, kdor živi med nami, lahko vidi in ve, kako se je ravnalo in se ravna s šolami in uradi...sploh z vsem, kjer koli bi se za pičico moglo svetu pokazati - da smo«/K, Č, ZD V, 248 /. »In ko bi bil...postrigel lase na pisker... /K. PO, ZD V, 31 / - zastar. »...nekaj let je prodajal platno - kakor pravijo...«/K, LP, ZD I, 251 /. Zdi se, da je ekspr. frazem, ki ga SSKJ ne navaja: »Ako si vrgel vero in vse njene pripadke čez plot...«/K, duhovnik, RV, ZD III, 175 /. Namesto glagola orati ima pisatelj: »...dobro (je) že za plugom hodil...«/K, PZL, ZD IV, 34 /. K frazeologiji

4 Janez Kersnik in njegov čas, Kranj 1997, Viktor Majdič: Kersnikov pogled na jezik. 
prištevam tudi »tačas je obrnila tudi Helena svoj pogled vanj...«/K, GJ, ZD I, 211 in še na isti str. 211 /. Včasih imamo razbit frazem v dveh stavkih, npr.: »... a pogled, s katerim je premeril razcapanega mešetarja...«/K, T, ZD III, 138 /. Jedrna beseda pogled ima ob sebi različne glagolske komponente: srečati /K, C, ID II, 41 /, ujeti /K, C, ID II, 59 /, upreti /K, NŽ, ZD I, 79, 117; C, ID II, 138; RV, ZD III, 231; GJ, ZD I, 191 /, vreči /K, RV, ZD III,160; PO, ZD V,116; RV, ZD III, 149; DKP /K, B, ZD V, 176. SSKJ ima nedovršno komponento metati. Neoznačena sta frazema $v$ stavkih: »...in ni vedel, kako bi pričel pogovor, da bi ga zasukal potem na pravo stran «/K, A, ID II, 253 / in »...(župan) je bil jako slabe volje, odkar je izlezel iz postelje«/K, H, ZD II, 255 /. »Mrzel pot mu je lezel po čelu« /K, T, ZD III, 140 / - ekspr. Enako stilno oznako ima frazem: »Roman in drama sta zašla na kriva pota «/K, O, ZD V, 313 / in : »...ne bodo zahajali na kriva pota« /K, PZL, ZD IV, 33 /.

Značilno za Kersnikove literarne osebe je to, da jih pogosto prikazuje v gibanju, bodisi da hodijo bodisi da se peljejo s kočijami ali na vlaku (o tem teče beseda pri prislovnih frazemih). V Ciklamnu je »Hrast meril urnih nog svoj pot«/K, ID II, 121 / - na to jedrno besedo se nanašata glag. komponenti iti /K, RV, ZD III, 237 / in ločiti /K, LP, ZD I, 279 /. Kersnik ima inverzirano kopulo: »Koraki po majhni stezi iz doline navzgor vzbudili so pozornost... «/K, LL, ZD I, 137 /. Drugačno glag. komponento ima jedrna beseda:» Vinko...(je) vrnil pozornost...«/K, NŽ, ZD I, 45 /. V pomenu priložnost ima Kersnik: »...sedaj se mu je pokazala...prilika...« /K, RV, ZD III, 178 /.

V povesti Očetov greh je ob vrhuncu dejanja spregovorjen frazem: »Ti bodeš prisegel tu pred Bogom Vsemogočnim, Vsevedočim «/K, sodnik, ZD IV, 95 /. »Vse prste si oblizne!«/K, Pavel, JG, ID I, 172 / - ekspr. J. Jurčič ima v R redki frazem: »...metal je ostre puščice... «/ID IV, $19 /$. »...drugače bode puška pela «/K, Tine, NŽ, ZD I, 14 / - ekspr., tu gre za substitucijo jedrne besede šiba (frazeološke substitucije obravnavam v posebnem razdelku). 'Dokončno poračunati' pomeni frazem: »...slikar je sklenil svoj račun...«/K, NŽ, ZD I, 111 /.»...lepa iluzija (bi) šla rakom žvižgat. Vsaj meni se je tako godilo - ne da bi šel rakom žvižgat, bog me obvaruj...《 /K, PP, ZD V, 77 / - ekspr., ki jo še bolj podkrepi medmetna FE. »Z rameni migajo...«/K, LP, ZD I, 266, 286 / - pog. Stilno nevtralna sta frazema: »Topolščak je potegnil...rame $k v i s ̌ k u \ll / K$, T, ZD III, 82 /in »Razgovor potem ni mogel prav teči...« /K, H, ZD II, 252 /. V Očetovem grehu zapiše J. Kersnik FE: »...da bi se postavil po robu očetovim zahtevam...«/K, ZD IV, 106 / - ekspr. J. Jurčič ima v R: »...da bi ga France bil $v$ kozji rog ugnal«/ID IV, 65 / - ekspr., tj. premagal, bil boljši kot on. SSKJ in J. Kersnik navajata: »Na ta način ga dobiva iz prvih rok...«/K, PO, ZD V, 214 /. »Delo šlo mu je naglo od rok...«/K, LL, ZD I, 158 /. SSKJ: delo mu gre od rok (hitro dela). »Domači župan si mane roke...«/K. PZL, ZD IV, 62 / - FE je potrjena v SSKJ. »Božan je ...pomolil še z voza dol roko... /K, RV, ZD III, 261 /. Ta jedrna beseda se veže še z glag. komponentami:imeti /K, ZD III, 258, skleniti /K, RV, ZD III, 258 /, pričeti /K, H, ZD II, 286 / in vzeti /K, ZD V, 82 /. »Mir najinemu očetu«, katere besedice bi sicer dali kar na rovaš vročinske bolezni...«/K, O, ZD V, 291 /. SSKJ citira: na rovaš: na račun. SP 2001: poud., obogateti na rovaš revežev /na račun /.Ta frazem srečamo še v OG /K, ZD IV, 162 / in v RV /K, ZD III, 195 /. Od Julija Cezarja je UBZ v Jurčičevem stavku: »Ali France...pa se ni dal prego- 
voriti, da bi prestopil tudi on Rubikon...«/R, ID IV, 68 / - pomeni pa: narediti kaj odločilnega. Notranji predmet izraža FE: »Sanjal je težke sanje«/K, PZL; ZD IV, 43 /. V PO imamo namesto glagola kaziti UBZ: »Že nekaj časa sta zaporedoma celi deželi skazo delala«/K, ZD V, 105 /.

»Tu leživa in prazno slamo mlativa«/K, Božan, RV, ZD III, 193 / - ekspr. »Ako se zlažeš, pridemo ti na sled ... «/K, sodnik, OG, ZD IV, 95 / in » $\underline{\text { Smeh mu je legel }}$ časih okrog usten... «/K, C; ID II, 74 /. »Štupa je hotel počiti od smeha«/K, RV, ZD III, 211 / - ekspr. V SSKJ je BZ, ki jo ima Kersnik v stavku: »...na Vaših krasnih ustnicah igra smehljaj vzvišenosti... «/PO, ZD V, 13 /. »...potlej te že smrt tiplje« /K, neki kmet, NŽ, ZD I, 11 / in »Morda je danes še pri volji dati to, kar sem rekel, jutri pa besedo sne!«/K, Lukec, OG; ZD IV, 129 / - ekspr. »...ko si je guvernanta otrla solze iz oči...«/K, RV, ZD III, 274 /. » Solze so mu silile v oči «/K, PZL, ZD IV, 45 /. »...solze so tekle...«/K, PZL, ZD IV, 46 /.

$\mathrm{Z}$ jedrno besedo sonce imamo pet frazemov z glag. komponento sijati $/ \mathrm{K}$, Veronika, NŽ, ZD I, 66 /; /K, LP, ZD I, 269, 269 /; /K, NŽ, ZD I, 105 /, glag. posije /K, Č, ZD V, 276 /. »...tako godrnja, ko ga že objemlje spanec«/K, OG, ZD III, 130 / - rus. bi bilo: v objatijah Morfeja, kar izhaja iz grške mitologije. Personifikacija glagola zaspati je v FE: »Mlajšim je spanec kmalu zatisnil oči«/K, RV, ZD III, 187 1. »...tudi naš Mesija, ki nas bo zbudil, kakor pravijo naši pesniki, iz trdega, težkega spanja... /K, $\mathrm{KO}, \mathrm{ZD} \mathrm{V,} 118$ / in »...nade poln poet, ki budi Slovenijo in Slovence iz dolgega, trdega spanja... «/K, PO, ZD V, 119 /. V obeh stavkih gre za poetično stopnjevanje pomena jedrne besede. Namesto glagola umreti uporabi Kersnik frazem: »Omagala je in zaspala mirno tja $v$ večno spanje «/PZL, ZD IV, 85 / - ta frazem je tudi v povesti OG, le glagolska komponenta je nedovršna / ZD IV, 118 /.

$\mathrm{Z}$ jedrno besedo srce sem našel devet frazemov: »...pretrese bralca do dna srca.... $/ \mathrm{K}, \mathrm{O}, \mathrm{ZD} \mathrm{V}, 317 / 318$ /. Ob jedrni besedi se uporabljajo različne komponente: govoril iz /K, RV, ZD III, 234; OG /K, ZD IV, 122 in v Č /K, ZD V, 257 /, polagal na /K, D, ZD V, 348/, segati do /K, duhovnik, RV, ZD III, 220 / in tesno pri /K, PZL, ZD IV, 40 /. Komponente imajo ustrezno vezavo. V naslednjem zloženem stavku imamo dva različna frazema: »Maruša je izlila očito ves žolč in vso jezo, kar se ji je bilo kuhalo $v \underline{\text { srcu }} / \mathrm{K}$, JG, ID I, 152 \%. »Krenil sem peš proti - Hrovatu in srce moje me ni varalo«/K, PO, ZD V, 177 /.

»...dohtarju je bilo enkrat izobčenje zažugano, tedaj ko je sedel med dvema stoloma...! / /K, PO, ZD V, 157 /. »Med dvema stoloma - to je bridka pa jako pogosta nezgoda...«/K, PO,ZD V, 157 / - tu je elipsa glag. sedeti. »Veronika, ki je stala s Sorijem na strani... «/K, NŽ, ZD I, 80 /. Z drugačno glagolsko in predložno komponento se rabi FE: »...ni skrbeti, da bi ga mlada dva kdaj osorno ogovarjala ali gledala po strani $/ \mathrm{K}$, OG, ZD IV, 117 /.

V Humoreskah imamo dvakrat navedeno FE: »...ti bi nas lahko spravil za nekaj dni pod streho! «/K, ZD II, 286, 287 /. Enak frazem še je v PZL, ZD IV, 72 /. Posamezno si slede frazemi: »...kadar človek udari kako novo struno «/K, LP, ZD I, 277 /. »...strojar, kateri je imel svoje petice že na suhem...«/K, H, ZD II, 251 / te FE nisem našel v nobenem slovarju, pač pa navaja SSKJ: imeti sušo v žepu (biti brez denarja). »...o tem si Vid sam ni bil $v$ svesti« /K, RV, ZD III, 189 / - zastar. "Luč sveta je zagledal tam na Dunajski cesti...«/K, PO, ID II, 308 / - star. Uvo- 
dni medmetni frazem izraža nekakšno zadovoljnost: »Hvala bogu, da mož ni nekaj stoletij prej zagledal luč tega sveta«/K, dr. Julius Repič, PO, ZD V, 21 /. Isti frazem z nedovršno glag. komponento srečamo v PO, ZD V, 186. V SSKJ je navedena kot nefrazemska BZ: šepetati na uho. Kersnik jo ima za frazem: »To sicer že sami veste, toda prijetne reči dva, trikrat komu na uho pošepetati...«/K, PO, ZD V, 211 /.

V Rokovnjačih ima J. Jurčič frazem: »...(rokovnjači)...so bili od nekdaj grozna šiba kmetu in gospodu«/ID IV, $15 / 16$ /. »Kregan je bil in malo je manjkalo, da ni šiba pela...«/K, PZL, ZD IV, 37 / - ekspr. »...pravijo, da ste si šstibale $n a$ oči nataknili...«/K, Peter Polenček, LL, ZD I; 16 / - star., ista oseba tudi reče: »Hoho, da imate šstibale, prave štibale na očeh!«/K, LL; ZD I, 162 /.

V RV beremo, da je graščakinja "poskušala spraviti drug pogovor $v \underline{\text { tir } « / K}$, A, ID II, 273 / - ekspr. »Njegove besede niso padale na kamnita tla«/K, JG, ID I, 180 \%.»...reče ona ter vzdigne počasi trepalnice... «/K, LL, ZD I, 140 /.»...marsikaj (sem) iz trte zvil«/K, PP, ZD V, 75 / - na omenjeni strani je isti frazem še dvakrat zapisan. »...temu je bolj glasno, bolj trdo udarilo na uho...«/K, C, ID II, 94 /. Te BZ ni v slovarjih, navedena pa je: »...le vleci na uho! « /K, T, ZD III, 111 / - ekspr., enako še nahajamo v T na str. 130 /K, ZD III /. - Kot nefrazemsko BZ navaja SSKJ Kersnikove besede: »Zakaj bi mi ne storil te usluge? « /RV, ZD I II, 198 /. J. Jurčič v $\mathrm{R}$ in J. Kersnik v H uporabljata enak frazem: »Ali nazadnje pak je stric Blaž, ko je bil sam, usta na široko odprl, oči raztegnil...«/ID IV, 48; K, ZD II, 251 /. Z nedov. glag. komponento srečamo to FE v T: »Ljudje po cerkvi so kar usta odpirali...«/K, ZD III, 107 /. »E, Pavliha, ti jih imaš še zmerom za ušesi«/K, Nedeljska pisma, ID II, 308 / - pog., šalj. »...ji ni prišlo na um...«/K, C, ID II, 70 / - zastar. V prislovni rabi je frazem: »...koliko (mesa) bo na upanje jemalo«/K, H, ZD II, 258 /. Frazem $\mathrm{z}$ jedrno besedo ura sem opazil le dvakrat $\mathrm{z}$ enako strukturo: »...so jim tekle ure" /K, A, ID II, 251; GJ, ZD I, 193 /. Jurčičeva UBZ: »Vleče na ušesa« /ID IV, 50 / - ekspr.; enako FE ima Kersnik v Člankih /ZD V, 236 /. »Kadar pa gredo na vas trije, štirje...«/K, LP, ZD I, 275 / in : »S to pogumno logiko sem bil tudi jaz danes utolažil svojo vest... «/K, PO, ZD V, 113 /. Jurčičev je frazem: »Jaz ti bom dal vetra...«/ID IV, 55 / - ekspr. Ta frazem navaja v celoti SSKJ. Nič nenavadnega ni, če imamo v Kersnikovem stavku po dva frazema: »Peter je igral svojo vlogo prav dobro « /GJ, ZD I, 223 /. V Podlistku Vieux Saxe X spet postavi pisatelj frazem v narekovaj: $-»$ Fedka Poddubni« pa bode pristoval lastniku »Slovanovemu«, ker oba igrata le »druge vloge«/ZD V, 186 /. Kersnikov je frazem: »Grof Aleš Auersperg je torej najbolj sposoben, Slovence na kisli vodi požirati...«/K, ZD V, 7 /. - Z jedrno besedo volja sem opazil štiri frazeme, kot so: »...on ni bil tako dobre volje«/K, RV, ZD III, 196 /; H, ZD II, 256; T, ZD III, 94 in 113 /. »Če vam pa ni prav, si pa vozel v

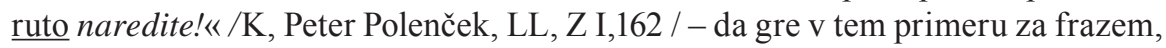
potrjuje navedek iz SSKJ: vozel na robcu ga je spomnil na dano obljubo. - »Sapramiš, rajši ti vrat zavijem...«/Jurčič, Bojec, R, ID IV, 52 / - ekspr.

Kersnikovi junaki se radi shajajo pri rujnem vincu »pijoči na zdravje in srečen zakon obeh zaročencev«/K, JG, ID I, 176 / - enako še v Člankih: Omega:«...pili smo ob Jurčičevih stroških še par litrov na zdravje...«/K, ZD V, 275 /. »In vendar je tekla njegova zibel v kmetski hiši«/K, LP, ZD I, 249 / - SSKJ navaja ta frazem s kvalifikatorjem knjiž. »...kdo mi bode to $v$ zlo štel...«/K, H, ZD II, 249 /. »Starke 
po potu čez zobe vlečejo tega ali onega...«/K, PO, ZD V, 46 / - zastar. »...(ni treba) zijala prodajati - «/K, LL, ZD I, 163 / - ekspr. V SSKJ ni FE: »Stresel je Jurco, da so mu zobje šklepetali«/K; T; ZD III, 102 \%. V slovarjih ni navedenega frazema »sikniti /sikati med zobmi«/K, T, ZD III, 121 / in /K, RV, ZD III, 176 / ter »med zobmi zabrlizgati«/K, T; ZD III, 97 /.

»...ako je Lipe s svojo nebeškolepo pesmijo: $v$ žakelj dal vse pesnike naše...« /K, PO, ZD V, 143 / - pog. »...na koncu se mi bo še želodec obrnil!! /K, adjunkt, Ciklamen, ID II, 21 / - ekspr. V slovarjih nisem našel FE: »...(odvetnik)...skrbi le za svoje pravde in za svoj žep «/K, A; ID II; 244 /. »...pustimo ga torej, da mu pride do živega!« /K, PO, ID II, 329 / in v RV /K, ZD III, 174 /. »Tisti teden je teklo doktorjevo življenje po starem tiru« /K, C, ID II, 53 / in »Maruša je izlila očito ves žolč in vso jezo...«/K, JG, ID I, 152 /.

\section{Frazemi s strukturo pridevnik + samostalnik}

Ti frazemi so glede na pogostnost na drugem mestu. Registriral sem jih 324, obravnavam pa prav tako kot prejšnje po abecednem redu jedrne besede. Vseh ne bom navajal, ker imam omejen obseg. V PO je frazem: »stare bajte«/K, ZD V, 156 / - živi v žargonu in pomeni študenta z mnogo semestri (SSKJ). V JG govore, da mora biti bal par«/K, odbornik, ID I, 195 /.

V Kersnikovi prozi sem srečal osem FE z jedrno besedo beseda, kot npr.: »Z dobro besedo...«/K, PZL, ZD IV, 34 /. Jedrna beseda ima ob sebi pridevniške komponente: laskave /K, ID II, 48 /, ostra /K, OG, ZD IV, 116 /, sladka /K, PO, ZD V, 161 /, tehtna /K, LP, ZD I, 250, 250 /, vezana in nevezana /K, OG, ZD IV, 131 / in žal beseda« /K, H, ZD II, 262 /. - »...(inženir) je nadzoroval pripravljanje hrastovih blazin «, tj. železniških pragov. BZ je sestavljen termin /K, ZD III, 84 /. Včasih vnaša J. Kersnik v slovenski jezik hrvaške lekseme, npr.: »...vojščaki so prihajali iz nje in divji, ljut boj se je pričel »/LP, ZD I, 258 /. V PO je UBZ: »...navdušenost naših rodnih bratov« /K, ZD V, 185 /. Jurčič zapiše v R: »...včasih sva bila vinska brata... /Blaž, ID IV, 46 /. V LP (Raztresenih listih) trikrat naletimo na frazem: črne brčice... «/K, ZD I, 249 /. »kurji britof «/K, PO, ZD V, 14, 55, 55 / in »kurji krištov« /55 / - nižje pog. V veseli igri Berite Novice: »policijske bukve«/K, ZD IV, 178, 179/- prvič ga spregovori Kratki, drugič pa Manica. V T beremo: »Lipi sta slični cvetno-nedeljskima butarama ...«/K, ZD III, 76 / - ta BZ je sestavljen termin. Frazem železna cesta je omenjen v Kersnikovi prozi osemkrat, kot npr. v LL /ZD I, 133 /, v OG dvakrat, v T /K, H, ZD II, 255 /, letni /K, H, ZD II, 258 / in prosti /K, GJ, ZD I, 196 /. Človek je lahko navaden /K, ZD III, 193 / in pošten /K, Manica, ZD IV, 174 \%. - O nenehno preteči nevarnosti govori FE: »...visi Damoklejev meč tudi nad trdimi glavami nas žurnalistov...«/K; PP, ZD V, 77; PO /K, ZD V, 156 /.

»Jedrna beseda dan se veže z različnimi izrazi: cel, lep, gorki, minuli, pasji, mili, spomladni, ljubi, pomladni, meglen, krasen, svet in živ (ne navajam virov zavoljo prostorske stiske!)

Denar je lahko debel in velik. »Krasna dežela je to« dejala je nadaljuje svakinjino opazko...»kakor bi mi bila rodna«/K, Helena, GJ, ZD I, 219 / - FE je razbita, 
komponente so v drugem delu zloženega stavka. Včasih poseže Kersnik v antično filozofijo, npr.: »-a danes ga je z Diogenovo svetilnico iskala...«/K, PO, ZD V, 182 1. Nekaj ironije je v frazemu: »A včeraj si jo je bil ta novi apostol ' ubogih na duhu $\therefore$... /K, PO, ZD V, 168 /. Enaka FE se ponovi v Domovini križem potovanja A, Iz Kravje doline v Kurjo vas: »To so literarni berači, ubogi na duhu... «/K, ZD V, 170 /. V JG: »...pokazal je takoj zli duh razpora svoje rožičke...«/K, ID I, 194 /.

$\mathrm{Z}$ jedrno besedo duša sem našel deset frazemov. Duša je lahko dobra, kosmata, nesramna, pasja, usmiljena in živa. Zadnji frazem ima tudi Jurčič v R, Kersnik v LP, H, C, A in LL.

»Topolščak v povesti Testament je preudaren človek, ki (je) dejal takoj z mirnim glasom...«/ZD III, 141 /. Inverzija pa je: »Resni ta glas... /K, NŽ, ZD I, 71 /.-

$Z$ jedrno besedo glava sem opazil le tri frazeme: »...stal je naš doktor še dolgo s povešeno glavo...! «/K, NŽ, ZD I, 99, 104 /. »Pa učenec Klun ima trdo glavo (on sam bi morda rekel $:$ bučo)...《/K, PPr III, ZD V, 82 / - kar je pejorativno. V T je duhovnik duhovni gospod /K, ZD III, $84 / 85$ /. »...vse ženstvo ni počenega groša vredno! /K, dr. Hrast, C, ID II, 96 / - ekspr. V noveli GJ je FE »duševna hrana « /K, ZD I,190 /- ekspr.

Jedrna beseda jezik ima štiri pridevniške komponente: hudi, hudobni, rodni in težki. Pomanjševalna jedrna beseda je v frazemu: »...Kretanov (se) strogo ogiblje 'žlahtne kapljice' in zlasti 'rujne' «/KPO, ZD V, 201 /. Petnajstkrat zapiše J. Kersnik termin zemljiška knjiga /D, ZD V, od str. 357-361 /. Kobila ali konj sta lahko iskra in čila. Lasje so lahko kostanjevi in kodrasti. Kruh je črn, bel, grenak in vsakdanji (zadnji se ponovi osemkrat). Pet različnih pridevniških komponent pojasnjuje jedrno besedo las: plavi lasje, rumeni, sivi, svetloplavi in svetlorumeni. Jedrna beseda leto je razvejana: mlada leta, novo leto, staro leto in srednja leta. Frazeološki somatizmi imajo v strukturi več različnih pridevnikov: lice je bledo, mrtvaško, odkrito in vroče - - »...videli smo namesto zlobnega, potuhnjenega, zvitega lisjaka - starikavega, smešnega deda...«/K, D, ZD V, 371 /. Ljubezen je 'petošolska', mlečnozoba petošolska, prva in prva vroča. Navada je stara in dobra. J. Kersnik ima v svojem predavanju Razvoj svetovne poezije FE: »Pa boj med temi elementi gre kot $r d e c ̌ a$ nit po vseh slovstvih, po francoskem in laškem, španskem in portugalskem «/D, Č, ZD V, 340 / - citirani frazem je pogostejši v knjižnem jeziku. Prirodne pojave slika takole: poletna noč, pomladna noč, poletnega opoldne, poletnega popoldne, poletni popoldan, pomladni dan, temna noč itd.

Nedelja je lahko cvetna in pustna. Velik krščanski praznik je velika noč $/ \mathrm{K}$, Č, ZD V, 259 , 261 in O /K, ZD V, 297 /. Nos je lahko kljukast, dolg, kriv, špičast ipd.

Najštevilčnejši je frazeološki somatizem z jedrno besedo oko /oči. Te so bistre, črne, modrosive, čudovite, iskre, mačje, žive, modre, temnomodre, povešene, jarke, temno obsenčene, rjave, temnorjave, temne, rdeče, solzne, sive, upadle...V celotnem proznem delu so največkrat prisotne črne oči. Sam Kersnik pravi: »Črne oči - to so moja slabost, moj pogin, moj zapeljivec...«. »Auch ich war in Arkadien geboren«, pa vse to mi ne brani, da ne bi storil nekaj nepotrebnih in nerodovitnih korakov za kako krasotico, ako ima črne oči« /K, Popotna pisma, ID II, 317 /. »...im wunderschönen Monat Mai; jaz pa sem stopal za črnimi očmi (citirana str.).« Črno oko »je 
zanj poetično«/K, PO, ZD V, 8 /. »Mene sta zanimali dve črni očesi«/K, LP, ZD I, 247 / - vseh FE s komponento črne sem preštel sedemnajstkrat. Oseba je lahko glavna ali odločevalna. FE 'pozemeljski ostanki' da Kersnik v narekovaj /PO, ZD V, 113, 113 / - SSKJ navaja: pokojnikovi posmrtni ostanki. V Podlistku Vieux Sax VII, Domovina križem potovanja, B - Iz Kravje doline v Kurjo vas, imamo na pol rusificiran frazem: »...žal, da sem ime pozabil, da ne, bi ga zabeležil tu v 'večnajo pamjat' /K, ZD V,176 /, rusko bi se pravilno glasilo: večnuju pamjat' , kar pomeni: slava mu, lahka mu zemljica. Ta FE ima v ruskem jeziku kvalifikator vis.

Obdobje največje poletne vročine izraža FE: »...v teh pasjih dnevih ...«/K, PO, ZD V, 109 /. Krščanski praznik je »veliki petek« /K, PO, ZD V, 215, 215, 215,216 in 218 /. Pred »veliko nočjo « je »veliki petek«/K, PPr, ZD V, 75 /. V Dodatku Slovensko gledališče poroča Kersnik: »Veliki ponedeljek je bila slovenska predstava...«/ZD V, 395 /. Frazem z jedrno besedo pogled nastopa šestkrat: Beseda se veže z različnimi pridevniki, kot so: hud, karajoč, srp, srep, zloben, jasen in poln. Pisatelj J. Kersnik ima frazem že v naslovu PZL, Znojilčevega Marka božja pot« /ZD IV, 36,36,37, 39 /. Drug pomen ima ta jedrna beseda $v$ frazemu: »...ta graščak, goni nervoznemu človeku mrzel pot na čelo«»/K, PO, ZD V, 152 /. Prislov v povedni rabi citira Kersnik trikrat: ni dosti prida, ni kaj prida in nič prida. »Torej je bridka resnica? « /K, Meden, C, ID II, 152 /. »...kdor ga je poznal, je trdil, da je pravzaprav 'pokrita

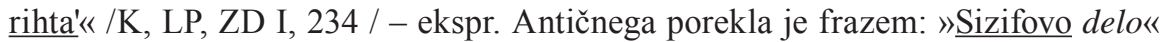
/K, D, ZD V, 383 /. Solze so bridke in grenke. Sonce je jasno, pomladno, jutranje, zahajajoče, zimsko, poletno in gorko. Notranji frazem je v primeru: »... dr. Janez Bleiweis, in ta spi mirno smrtno spanje... /K, PO, ZD V, 156 /.

Ne smemo pozabiti, da je J. Jurčič napisal le 11 poglavij zgodovinskega romana Rokovnjači, ostalih 13 pa J. Kersnik. Oba pisatelja sta se osebno poznala. Jurčič je prijatelju Kersniku vnaprej povedal, kako naj se zgodba razpleta. Kmetica Mozolka v Rokovnjačih pravi: »Kaj mislite, da bom jaz hčer dala na ajdovo strnišče?«/K, ID IV, 134 / - ta UBZ pomeni: dati hčer človeku, ki nič nima.

Praznično razpoloženje praznika velike noči uvaja: »Tihi teden je tu...«/K, OG, ZD IV, 116, 118 /.»Veliki teden nastopi čez malo ur...«/K, Č , ZD V, 259 /.»Pognala sta in trda tema ju je objela... «/K, T, ZD III, 130 /. Ura je lahko bridka, huda, srečna in zadnja. Usoda pa je bridka, nemila in srečna.

Naravne pojave zaznava pripovednik s širokim registrom. Jedrno besedo veter podaja s pridevniškimi komponentami: jesenski, južni, gorak in mrzel. Lahen veter je sapa, ki je gorka in južna.

»...povabi me v svojo gostoljubno hišo, in tam se je med nama pri kapljici rujnega vina in pri okusni bržolici...«/K, PO, ZD V, 172 /. »črna vojska«/K, PZL, ZD IV, 70, 72, 72 / - zastar. Volja je dobra, slaba in trdna. »...saj vem, da me bode kakšna ljubljanska tercijalka...razupila kot volka v ovčji koži«/K, PO, ZD V, 12 / - ta FE je vzeta iz Matejevega evangelija, 7, 15 /Ašukini, Krilatie slova, Moskva 1960, str. 107 /. - V humoreski Dva adjunkta imamo frazema: »državni zakonik» in »kazenski zakonik« /K, ZD II, 268 / - jur. - Večkrat srečamo FE z jedrno besedo žarek, ki je lahko gorak, jasen, sončni, divni in zlati. - Duhovnik sprašuje: »Kaj misliš o duši, o večnem življenju...«/K, RV, ZD III, 179 /. 


\section{Glagolski frazemi}

Vzporedno z imenskimi frazemi imajo tudi glagolski osrednje mesto v slovenski frazeologiji. Glagol nastopa kot jedrna beseda in je gramatični center celotne BZ, ki pa istočasno ohranja vse ali pa nekatere oblike spregatve. Glagolska FE, isto kot glagol, ima semantično funkcijo oznake dejanja, procesa ali stanja. V stavku se rabi kot povedek. Vendar pa FE z glagolsko jedrno besedo ne prištevamo h glagolskim frazemom tedaj, ko izgubi funkcijo glagolske besede, tj. da preneha označevati dejanje ali pa izgubi besedne oblike, značilne za glagol.

$\underline{\mathrm{H}}$ glagolskim frazemom prištevam take BZ, pri katerih jedrni glagol ohranja gramatične značilnosti glagola, tj. izraža leksikalne značilnosti glagola, in sicer označuje dejanje, trajanje ali stanje.

Glagolske FE so številne in različne. Po A. P. Mordvilkus se frazeološke strukture glagolskih FE ne razlikujejo od strukture glagolskih PBZ (prostih besednih zvez). Glagolske FE in glagolske PBZ imajo navadno obliko konjugacije, izražajo vid, naklon, čas, število in osebo. Neglagolska komponenta je najpogosteje samostalnik, včasih pa tudi beseda od drugih besednih vrst. Besede, nanašajoče se kot komponente na jedrni glagol, so v primerjavi z njim podrejene. Med njimi je sintaktična zveza rekcija/rus. upravlenie / ali vezava. V PBZ so take besede objekt h glagolu ali prislovna določila. Glagolski frazemi so pri analizi strukture stavka celota, ki je en stavčni člen. Temeljna razlika glagolske FE v primerjavi z glagolskimi PBZ je v leksikalno-semantični strukturi. V prosti besedni zvezi nastopajo besede v svojih direktnih, nominativnih pomenih, njih celotni smisel je seštevek vseh komponent, medtem ko gre pri glagolskih frazemih za spremembo neposrednega pomena, za spremembo komponent in semantike. Manj bistvena je gramatična naslonjenost komponente $\mathrm{k}$ temu ali drugemu stavčnemu členu. Glede na to razlikujemo glagolsko-imenske, glagolsko-prislovne, glagolsko-zaimenske...frazeme. Največkrat srečamo pri J. Kersniku glagolsko-imenske. Tu je treba upoštevati, da je včasih druga komponenta glagolskih FE izražena kot BZ, npr.:«Topolščaka (so) prvič oklicali pri zgodnji maši...«/K, T, ZD III, 104 /.

V Kersnikovi prozi je največ frazemov naslednjih tipov: a) Glagolske FE s prenesenim pomenov vseh avtosemantičnih besed (nem. haupsächliche Wörter, rus. знаменательные слова), sestavljajočih frazem, kar je pravzaprav preneseni pomen celotne FE in b) Glagolski opisni izrazi, oblikujoči se paralelno z bližnjimi po pomenu in navadno etimološko sorodnim /enokorenskim / glagolom, kot npr.: »...(Kalander) se je čudom čudil...«/K, T, ZD III, 125 / - tj. zelo se je čudil. »...da bo kmalu še več pesmi na svetlo dal« /K, Miha, LP, ZD I, 245 / - tj. izdal - omenjena FE je že arhaična.

\section{Glagolski frazemi s prenesenim pomenom celotne besedne zveze}

Malo je glagolskih frazemov, katerih trdnost (rus. устойчивость) temelji na tem, da se vse komponente, izražene $\mathrm{z}$ avtosemantičnimi besedami, uporabljajo $\mathrm{v}$ prenesenem pomenu. Takšen je ekspr. frazem:«...strastno se je utapljal vanj...da 
mu bode mogel duška dati...«/K, A, ID II, 237 /, kar pomeni izraziti na neki način svoje čustveno razpoloženje. Jože Toporišič bi poimenoval te FE zrasleke in sklope. »Mešetar je spoznal, da je bolj resen in da mu gre sedaj za kožo...«/K, H, ID I, 119 / - FE pomeni, da je ogroženo življenje. » - naj ne pijem 'rujnega vinca' v družbi 'divnih' feljtonistov in prijateljev, da naj se ne oziram na desno in na levo, kje morda bog svojo roko ven moli...«/K, PO, ZD V, 179 / - tj. šalj. za gostilno. - Glagolski frazemi tega tipa označujejo $\mathrm{v}$ večini primerov dejanja človeka, povezana $\mathrm{z}$ medsebojnimi odnosi, označujejo pa tudi psihična stanja človeka. Vzrok za to je iskati v tem, ker ravno dejanja in stanja človeka, povezana z njegovimi medsebojnimi družbenimi odnosi, bolj kot druga dejanja, potrebujejo prenesen, izrazen ton.

Semkaj prištevamo FE (tu in tam že arhaične), kot npr.: »Oprežnim nam je biti!«/K, poštar, H, ZD II, 252 /. »...dejal jih je (besede) na račun originalnosti tega moža...«/K, NŽ, ZD I, 32 /.»...tega pa ne morem, da bi ljudje za menoj kazali!« /K, mati, LL, ZD I, 162 /. »... (s premoženjem) pa je šlo navzdol rakovo pot« /K, KS, ID I, 40 / - ekspr. »Kaj bi iz suhega prelival v pusto?« /K, OG, ZD IV, 123 / FE ni potrjena v slovarjih. V slovarju ME je naveden ruski frazem: переливать из пустого в порожнее s kvalifikatorjem pog., pomeni pa: mlatiti prazno slamo. »... ne bom več po svetu trave tlačil «/K, NŽ, ZD I, 11 / - evfem. Del slovenskega reka da pisatelj pod narekovaj: »... z 'volkovi tuliti' /K, PO, ZD V, 168 /.»...in $v$ kozji rog se tudi ni dal ugnati« /K, H, ID I, 119 /. »...zaradi sebe sem se zjokal, bridko zjokal...«/K, Pesmi v prozi, ZD I, 278 /. »Ako si je Molek kaj v glavo vtepel, izvršiti je moral... / /K, H, ID I, 95 / - ta frazem se pogosteje vzpostavlja z nedovršno jedrno komponento, tj. : vtepati v glavo (SSKJ). - V govoru o F. Levstiku beremo: »Pozabiti pa ne smem in ne morem resnice, da je vse, kar je znamenitega do časa Levstikove bolezni zagledalo beli dan na našem slovstvenem polju, da je vse to šlo skozi njegove roke...«/K, Č, ZD V, $271 / 272$ / - v tem zloženem stavku sta dva frazema: prvi pomeni natisniti /iziti, drugi pa prebrati /preštudirati. Grobost je izražena v FE: »Zaklel je med zobmi...«/K, NŽ, ZD I, 64 / - SSKJ te BZ ne navaja. V T je FE: »Začul je sedaj korake in zažvižgal med zobmi«/K, ZD III, 131 /. Stara ženica pravi: »Jaz vam želim vse dobro...«/K, NŽ, ZD I, 122 \%.

Frazemi s strukturo samostalnik + samostalnik (vezava med njima je lahko vezniška ali predložna)

»Ti si moj angel varuh, če ima človek angela varuha«/Jurčič R, ID IV, 58 /. »No, no, beseda ni konj...«/K, Simon, KS, ID I, 52 /. »...oni zakoni, ki urejajo medsebojno življenje - vse gole posledice boja za obstanek«/K, Božan, RV, ZD III, 275 / - biol. »Tam v kamrici se je že od nekdaj zbiral cvet srobotiške inteligence« /K, H, ZD II, 248 /. Večkrat sem opazil frazem: »Odslej je hodil Kosan dan za dnevom na Potok...«/K, LL, ZD I, 157, 158; JG, /K, ZD I, 206; v Člankih Pomagajte kmetu /K, ZD V, 257; K, A, ID II, 243 /. V Podlistkih se je k temu frazemu, ki označuje čas, pridružil še en: »...dan za dnevom, leto za letom...«/K, ZD V, 14 /.

V Gledaliških ocenah, Slovensko gledališče imamo FE: »...pripoznati ji moramo, da je bila izvršitev njene role izvrstno delo... «/K, D, ZD V, 384, 393 /. J. Jurčič omenja v R: »...rokovnjači nimajo tega praprotovega semena že sami, oni, ki vedo že od nekdaj od roda do roda stare copre in vse stare križ besede«/ID, IV, 66 / - ta 
frazem mi je razvozlal akad. prof. Jože Toporišič v maju 2004. Prva FE je frazeoshema, kar je redek pojav v Kersnikovi prozi. V povesti OG imamo drug ob drugem kar dva frazema: »- obe sta vsaka v svoji dobi noč in dan, leto za letom...«/K, ZD IV, 153 /. Elipsa komponente metati je v frazemu: »Kajti nova, tako nova, kakor je stara prislovica:«...pesek $v$ oči $/ \mathrm{K}, \mathrm{PO}, \mathrm{ZD} \mathrm{V}, 9 \mathrm{o} /$. »Cvenk in žvenk«, to je danes geslo...«/K, PO, 45 / - ekspr., frazem se uporablja samo v ednini.

\section{Frazemi s strukturo predlog + samostalnik ter predložnosklonska oblika samostalnika}

$» \mathrm{~V}$ Borju je volivno gibanje rastlo od dne do dne«/K, A, ID II, 262, 263, 264; R, ID IV, 163; PO, ZD V, 20; Č, ZD V, 256, 256 /. V noveli GJ imamo FE: »-ker bi te i jaz zaničeval iz vse duše svoje!«/K, ZD I, 229 /. »Smejejo se na vse grlo... «/K, D, ZD V, 371 / - ekspr. »No, ta je vendar srečno pod kapom!«/K, davkar, JG, ID I, 182 /. »...prvi je bil Luka na licu mesta ...«/K, H, ID I, 120 / - ta frazem preganja SP 2001. »... kolega je računal po stari navadi... /K, LP, ZD I, 237; RV ZD III, 200 in LP, ZD I, 236 /. Majhen odklon od določene smeri pomeni FE: »...v drugem dejanju je zabredel za pičico v pretiranje... /K, D, ZD V, 337 /. Dvakrat srečamo FE: »Nejče (je) pritrdil vprašanju, ali je vse $v \underline{\text { redu }}$ /K, H, ZD II, 293, 293 /. - Jedrna beseda srce ima štiri različne predložne komponente, in sicer : $i z, n a, v$ in $d o$.

$\mathrm{V}$ več slovanskih jezikih je FE: »od naše strani«/K, D, ZD V, 355, 356 / - tu je treba reči, da obstaja ta frazem v poljskem, ruskem in shrv. jeziku z ustreznimi leksemi. Nekakšen čustveno časovni razmik kažeta frazema: »...želja po maščevanju rastla mu je od ure do ure «/K, LL, ZD I, 172 /. »Od dne do dne, od ure do ure čakam«/K, PO, ID II, 320; SSVVK, 219 / - kar sta tavtološki frazeoshemi, prav tako kot: »...šel je od ust do ust...«/K, LP, ZD I, 253; srečamo še ga v Č in dvakrat v JG. Fonetična beseda je na videz, v Kersnikovem proznem delu sem jo opazil trikrat, in sicer v JG, GJ in v RV. »...dela od zore do mraka«/K, IRL, ID I, 9; prisotna še je v LP, KS, H, T in v »Govoru o F. Levstiku« /K, ZD V, 267 / - ekspr.

Zaimensko-predložno-pridevniških frazemov skorajda ni v Kersnikovi prozi. Navajam samo primer: »- tam na Brdu pa se ga je udeležila celo nedolžna deca torej vsi do zadnjega!«/K, PO, ZD V, 189 /.

\section{Samostalnik + predlog}

»To je boj, samo boj za obstanek!«/K, RV, ZD III, 259 / - biol. V LP je FE: »... da je nosil nekdaj čevlje na kveder...«/K, ZD I, 252, 253 /. Trajnost dogajanja izraža FE: » - toda dan za dnevom je bilo bolje...«/K, GJ, ZD I, 192; LL /K, ZD I, 173 / in v PO, ZD V, 14, 144. »...te ljudi sovražim, iz vsega srca jih sovražim...«/K, ID II, 221 /. » - vse je bilo elegantno in po najnovejši šegi«/K, GJ, ZD I, 212 / - zastar. V povesti LL imamo $v$ naslednjem stavku dva frazema: »...po gradu bilo je kmalu na videz vse $v$ globokem spanju «/K, ZD I, 168 /. »In tako naglo - na vrat na nos..." /K, T, ZD III, 107 / - ekspr. (vseh tovrstnih FE ne navajam).

\section{Samostalnik + števnik}

Teh frazemov ni veliko v Kersnikovi prozi. Za ilustracijo navajam le štiri: »Prva in zadnja beseda tam tiče se volitve!«/K, Ruda, A, ID II, 250 /. »...solze 
prvega spoznanja, prve bridke ljubezni«/K, NŽ, ZD I, 88 /. »Majhna, na prvi pogled neznatna slika...«/K, LL, ZD I, 131 /. »Vera in sploh vsa filozofija mu je bila deveta $\underline{\mathrm{skrb}} \ll / \mathrm{K}, \mathrm{C}, \mathrm{ID}$ II, 81 \%.

\section{Zaimek + pridevnik ter zaimek + samostalnik}

»...Ta je bosa«/K, dohtar, KS, ID I, 70; enako še v A /K, ID II, 234 /. »Oj, ta je lepa!«/H, ZD II, 265 /. »Ta je prazna«/K, OG, ZD IV, 129 /. »In nekaj resnice je moralo biti v tem...«/K, H, ZD II, 253 /. »...naše gore list«/K, O, ZD V, 268 /.»... Bog pa te bode kaznoval na tem in na onem svetu... / /K, OG, sodnik, ZD IV, 95 I. - Jurčičev jezik v R se v marsičem ujema z jezikom Kersnikove proze, to se pravi, da oba pisatelja zgodovinskega romana vnašata $\mathrm{v}$ jezik med drugim tudi enake frazeme: »...Pavle, dve leti mlajši od Polonice, bolehal je že na prsih in bati se je bilo, da pojde za isto boleznijo kot oče in bratje mu s tega sveta«/R, ID IV, 36 /. Frazem v prislovni rabi: »Pri tebi je menda vsak petek - svetek, prijatelj!«/K, T, Tomaž, ZD III, 110 \%.

\section{Frazemi s strukturo zaimek + prislov}

Ti strukturni tipi so maloštevilni, navajam le: »...zakaj se je Dora kar tako meni nič tebi nič...odpovedala Rihardu? / /K, O, ZD V / - ta frazem kot ekspr. navaja tudi SP 2001. Enako FE imamo tudi v Kersnikovem jeziku R, 166, v veseloigri Berite Novice /K, ZD IV, 178 / in v D, O /ZD V, 387, 388 /. Frazem »kakor nalašč« imamo v RV, 20, 168 in v OG, 137.

\section{Frazemi s strukturo zaimek + glagol + prislov}

Tudi teh ni veliko. Navajam dva: »...vse bo vrag vzel, vse pojde križem, vse« /K, BN, Kratki, ZD IV, 175 / - tu gre za stopnjevanje dveh pog. frazemov. »Prav dobro smo se imeli!«/K, Štupa, ZD I, 213 /.

\section{Frazemi s strukturo prislov + glagol}

»- čudom se je bilo čuditi - «/K, JG, ID I, 185 /. Zanimivo je, da navaja Kersnik vojaška povelja $\mathrm{v}$ slovenščini, čeprav je bila $\mathrm{v}$ 19. st. poveljujoč jezik le nemščina, npr.: »...znal ni, kaj se pravi 'na desno kreni .'. ' na levo glej'...!«/K, H, ZD II, $282 \%$

\section{Prislov + števnik + samostalnik}

Teh frazemov sem preštel trinajst, npr.: »Golobje življenje med štirimi stenami...«/K, JG, Pavel, ID I, 179 /.»...jaz bivam tudi med štirimi zidovi...«/K, NŽ, kontesa, ZD I, 24 /. V več slovanskih jezikih je FE: »...na vse štiri strani sveta«/K, O, ZD V, 288 /. Le enkrat samkrat sem opazil frazem s strukturo: samostalnik + predlog + števnik + samostalnik: »...neumna je, da bi verjela, da je mesec na štiri ogle...«/K, C, ID II, 120 /.

\section{Nikalnica ni-ni, ne-ne + samostalnik ali glagol}

»O bratu nadlajtnantu pa ni bilo ni duha ne sluha«/K, LL,ZD I, 105 / - ta FE 
se večkrat ponovi. Jurčičeva je FE: »...ne živ ne mrtev, sama kost in koža« /R, ID IV, 38 / - tj. klimaks na frazeološki ravni.

\section{Prislov + veznik + prislov}

Najpogosteje kažejo te vrste frazemi krajevno določitev in so prisotni v vseh Kersnikovih delih. Po obliki niso pestri, so pa zelo pogostni, npr.: »...(Vinko) roma počasi po sobi gori in doli«/K, NŽ, ZD I, 46, 46, 60 /. V LP je zreducirana oblika : »gor in dol«/K, ZD I, 246, 256 /. FE se ponovi 14-krat. »...(rosne kaplje) so visele krog in krog «/K, NŽ, ZD I, 14 /; FE je registrirana 7-krat v različnih delih. Najpogostejša je UBZ: »sem ter tja«/K, H, ZD II, 250, 286; ponovi se 26-krat. Dokaj frekventen je frazem: »tu in tam《/K, LL, ZD I, 157 /, ki se ponovi 26-krat. Prislovno-časovni frazem sem opazil le dvakrat, npr.: »zdaj pa zdaj«/K, A, ID II, 181 / in NŽ /K, ZD I, 132 /.

\section{Stavčni frazemi in medmetni frazemi}

»In bog ga vedi - kam pride? /K, Topolščak, T, ZD III, 93 /. »Oh, vrag vedi, da ni nič...«/K, Topolščak, T, ZD III, 120 /.»...Bog vedi in sveta pomagalka«/K, Barba, A, ID II, 276 /. »- bog se usmili«/K, Č, ZD V, 252 /.»...bog nas varuj...« /K, PO, ZD V, 168 /. »Bog te živi - gospod sosed!«/K, kontesa, NŽ, ZD I, 24 /. »Bog ji daj dobro na onem svetu... «/K, Blaž, R, ID IV, 88 /. Srditost, nejevoljo in nestrpnost izraža frazem: »Kaj za boga vendar...«/K, NŽ, ZD I, 44 /. Podoben pomen ima frazem: »Za boga svetega...«/K, A, ID II, 206 /. Vznemirjenje in strah se kažeta v frazemu: »Oh, moj Bog!«/K, dekle, A, ID II, 254 /. Ta FE se ponovi še 7-krat. »...hvala bodi Bogu in čast«/K, NŽ, ZD I, 15 /. Stavčni frazem je tudi: »Sam bog bodi zahvaljen...! /K, Kratki, BN, ZD IV, 117 / - vznes. »Za božjo voljo...«/K, R, ID IV, 132 /. V LL nahajamo FE: »Za Kriščevo voljo, kaj pa je?«/K, kmetska žena, ZD I, 134 /.

V veseloigri Berite Novice: »Za božji čas ?«/K, Manica, ZD IV, 186 /. Ta UBZ je samcata v celotnem Kersnikovem literarnem ustvarjanju. V Dodatku Slovensko gledališče: »Bog mu jo 'žegnaj' ! «/K, ZD V, 385 /. Medmetni frazem je v stavku: »Tam sem izpraznil poln kozarec na Vaše zdravje...«/K, PO, ZD V, 231 /.

\section{Frazemi - obrazci, etikete}

$\mathrm{K}$ frazeologiji prištevam tudi izraze pri pozdravljanju, odgovorih na pozdrav in pri slovesu. Najpogostejši je pozdrav: »Dober dan, oče, danes kmalu pridete!«/K, Manica, BN, ZD IV, 175 /. »Dobro jutro, Tine!«/K, gospica Ana, NŽ, ZD I, 161 /. Ta FE se večkrat ponovi. Preden gremo spat, rečemo: »Lahko noč! «/K, deklica, LL, ZD I, 160 /. FE se ponovi 8-krat. Ob slovesu rečemo: »Na svidenje! « /K, LL, ZD I, 182 \%. »Na veselo svidenje! «/K, D, ZD V, 398 /. Zvečer se Slovenci pozdravljamo s frazemom: »Dober večer, gospodična Franca...«/K, LP, ZD I, 241 /. V romanu A vošči Koren: »Veselo novo leto! «/K, ID II, 210 /. Topolščak vošči: »Dobro zdravje, Brnot!«/K, T, ZD III, 91 / - FE se ponovi 3-krat. »Pa naj bode - vesele praznike Vam želi Vaš Per«/K, PO, ZD V, 187 /. 


\section{Folklorni frazemi}

Semkaj prištevam frazeme, izhajajoče iz slovenske narodne tvornosti. Največ je okrasnih pridevkov, kot npr.: »bela cesta «/K, GJ, ZD I 224 / - ponovi se 11-krat. »beli dan« /K, LP, ZD I, 275 / - ponovi se pri J. Kersniku 6-krat in pri J. Jurčiču 1-krat. V KS: »...kjer se je blesketal v svitu zahajajočega sonca bel gradič«/K, ID I, 76 /. »bela cerkev ... «/K, ZD IV, 122 /123 /. »bela Ljubljana ... /K, PO, ZD V, 174 /. »širni beli svet« /K, LP, ZD I, 254 / - ponovi se 8-krat. »črna zemlja«/K, ZD I, 236, 254 /. V humoreski Kako je stari Molek tatu iskal imamo zaklinjanje: »Gad in gadica, modras, modrasica, kača, kačon - «/K, starka Mesojeda, ID I, 123 /.

\section{Primerjalni frazemi}

V prozi J. Kersnika sem našel 37 primerjalnih frazemov. Uvajajo jih vezniki kakor, ko in kot, npr.: »...kakor blisk iz jasnega...«/K, ZD V, 74 /. »mrzel ko led« /K C, ID II, 45 /. »zdaj spi kot polh«/K, ID IV, 50, 99 /.

\section{Religiozni frazemi}

Teh frazemov je okrog 30, kot npr.: »Bog mu grehe odpusti«/K, ZD I, 235 /. »Bog te obvaruj!«/K, ZD I, GJ, 208 /.»V prvem letu po novi maši...«/K, GJ, ZD I, 190 /. »... duh božji je plaval nad vodami » /K, LP, ZD I, 270 /. V JG imamo biblijski frazem: »...župnikov poziv tudi ni ostal glas vpijočega v puščavi«/K, ID I, 181: Izaija, 40, 3; frazem je citiran tudi pri Mateju 3.3 in še na drugih mestih Svetega pisma /. »Star kmetski mož je molil litanije vseh svetnikov in svetnic«/K, LP, ZD I, 253 /. »Križana nebesa, kaj čemo zdaj?«/K, Megla, C, ID II, 17 /. V povesti OG moli mati Barba: »-oče naš, kateri si v nebesih...in odpusti naše dolge, kakor...«/K, ZD IV, 120 /. Ta molitev se imenuje Očenaš, na kmetih so ga molili večkrat dnevno. Iz Lukovega ${ }^{6}$ evangelija je stavek: »Oče, odpusti jim, saj ne vedo, kaj delajo!«/K, ZD V, 24 /. Biblijska je tudi UBZ: »Ako vsadimo pšenično zrno v plodno zemljo, pognalo bode kal (7) «/K, D, Č, Razvoj svetovne poezije, ZD V, 328 /. Kersnikov jezik v Rokovnjačih omenja priliko: »Povej mi, zakaj se je 'izgubljeni sin vrnil $k$ očetu? /K, ID IV, 92 I.»Vi ste sol zemlje, ako se pa sol spridi, sčim se bo solilo?« piše evangelist Matevž v petem poglavju /K, PO, ZD V, 44 /. Evangelijskega izvora je izrek: »Blagor onim, ki so nedolžnega srca«/K, PO, ZD V, 11/. V PZL je navedena 4. božja zapoved: »Spoštuj očeta in mater, da boš dolgo živel in se ti bo dobro godilo«/K, ZD IV, 40 /. Jedrna beseda vrag ima komponente: vzel, vzemi, jezik, kaj. Nekoliko bolj milo zveni kletev: »Da bi te zlodej!«/K, R, ID IV, 115 /.

\section{Krilatice, pregovori in reki}

Krilatice so UBZ, podobne pregovorom in rekom, izhajajo pa iz znanega literarnega ali zgodovinskega vira. Pregovori so prenesene BZ, ki imajo poučen smisel in navadno specifično ritmično-fonetično obliko. Reki so tudi prenesene BZ, ki se razlikujejo od pregovorov po svoji sintaktični nedokončanosti.

V Kersnikovi prozi je največ pregovorov, sledijo reki in krilatice. Pregovor že imamo v R: »A res ni dosti manjkalo, da niste po vseh štirih lezli; ko bi bili sami,

6 Sveto pismo stare in nove zaveze, Ljubljana 1974, Luka: XXIII. Poglavje, 34. vrstica. 
bili bi že ali po vseh štirih lezli kakor 'biba leze, tovor nese'... «/Jurčič, ID IV, 44 /. Kalamburno strukturo postavi Kersnik v narekovaj, medtem ko navaja SSKJ: biba leze, biba gre. V Podlistkih, Popotna pisma IV, V Višnji gori je v uvodu k naslovu Kersnik zapisal pregovor: »Bog daj norcem pamet!«/K, ZD V, 104 /. Naslednjo BZ poimenuje sam pisatelj kot pregovor: »Bog roko ven moli!«/K, PZL, ZD IV, 52 / - ta pregovor pomeni gostilno. Različni narodi imajo pregovor: »Denar, sveta vladar« /K, Slovensko gledališče, ZD V, 374 /. V Podlistku Vieux Saxe je pregovor: »... boljši je, drži ga, kakor lovi ga«/K, ZD V, 157 /. Menim, da je slovenski pregovor: »Kdor ne ljubi petja, bab in vina, ostane žive dni neumna živina«/K, LP, ZD I, 273 /. Več narodov ima pregovor: »...stara ljubezen ne zarjavi!«/K, notar, JG, ID I, 156 1. Omenjeni pregovor imajo Hrvati, Nemci, Rusi in morda še drugi narodi. »Pregovor, da nove metle dobro pometajo, čutili so vsi na graščini... «/Jurčič, R, ID IV, 71 /. Preoblikovan je pregovor v šaloigri BN: »Od dobre gospodinje poje pismo, da tri ogle hiše pokonci drži, a jaz držim pet oglov naše kanclije pokonci, pet, še več kot vse štiri ogle »/Kratki, BN, ZD IV, 175 /. E. Bojc citira: »Pridna ženska tri vogle (hiše) podpira pa še četrtega pomaga možu nositi《/str. 105 /7. »In ne bo kruha iz te moke« /K, KS, ID I, 70 / - enako je pri E. Bojcu. Avtorski je pregovor: »...poezija in prazen želodec se ne strinjata«/K, C, ID II, 137 /. V Ocenah Balade in romance citira Kersnik verz iz Aškerčeve pesnitve Stara pravda: »Car daleč, a Bog je visoko!«/K, ZD V, 303 / - ta rek je vzel Aškerc iz ruščine: Царь далеко - Бог высоко. Slovenci nismo imeli carja, ampak cesarja. Ranocelnik iz JG izreče latinski rek: » - saj veš: in vino veritas - «/K, ID I, 188 /. Kersnik ima za narodno uganko priredno organiziran stavek: »To je tisto, kar je majhno ko ajdovo zrno, pa vendar težko kladivo privzdigne...«/K, PO, ZD V, 191 /. - V članku Pomagajte kmetu je svetopisemski rek: »V potu svojega obraza boš služil svoj vsakdanji kruh...«/K, ZD V, 256 /. Stritarjansko sentimentalno zveni rek: 'vsega sveta gorje'...«/K, Corpus juris, ZD I, 235, 236 , 237 / in v LP, Raztresenih listih IV, preide ta frazem v hiperbolo: »Vesoljnega sveta gorje«/K, ZD I, 255 /. Prav gotovo je resnična krilatica: »Pota božja in pota ljubezni so nerazumljiva«/K, Pisma iz Gradca I, ZD V, 73 /.

\section{Citati}

V Kersnikovi prozi je precejšnje število citatov. Večinoma so slovenski, sledijo nemški, latinski, francoski in starogrški. Zbral sem štiriinosemdeset citatov, navedel jih bom le nekaj, npr.: De gustibus non 'disputandibus'! /K, S slavnostnim vlakom, ZD V, 228 /. »Vsi pojte rakom žvižgat...«/K, Molek, H, ID I, 125 / - tu je naveden prvi verz iz Prešernove pesmi Zvezdogledom. »Hrast se omaja in hrib - a mi, citiral je prišlec...«/K, A, ID II, 94 / - tu gre za verz Koseskega. V PO, Nedeljskih pismih, citira Kersnik 1. verz pesmi S. Jenka Naprej: »Naprej zastava slave!«/ZD V, 17 /8 (9). V PO, Popotnih pismih, imamo nemški frazem: »Ritter vom heiligen Grabe «/K, ID II, 311 /. Bole iz C pove po italijansko: »Kako krasen salto mortale ste napravili...«/K, ID II, 57 /. Reminiscenca na velikega nemškega pesnika Goetheja je verz iz Fausta: »Ein garstig Lied, pfuj! Ein politisch Lied!« /K, Bole, C, ID II,

7 Etbin Bojc: Pregovori in reki na Slovenskem, DZS, Ljubljana 1980.

8 Simon Jenko: Izbrano delo, MK, Ljubljana 1976. 
29 /. - Kersnik kot pisatelj in pesnik je bil tankočuten do Gregorčičevega muzikalno harmoničnega verza. V Podlistku Stricu v Ameriko se sklicuje na Gregorčiča9: Gregorčič poje: »Uzore pokopali so... /na grobu tam plesali so...《/K, ID II, 329 / verza sta vzeta iz Gregorčičeve pesmi Moj črni plašč, navedena je 7. kitica, 1. in 3. verz. Sicer pa goriškega slavčka navaja še večkrat. V povesti OG je moto: »Jaz sem gospod, tvoj Bog, goreč Bog, /ki pokorim krivico očetov na otrocih do /tretjega in četrtega rodu...«/K, ZD IV, 93 / - V. knjiga Mojzesova, V. pogl., 9. vrsta.

V Ciklamnu nas junak Bole ne preseneča tudi tedaj, ko govori francosko revolucionarno pesem in državno himno: »Allons, enfants de la patrie! «/K, ID II, 53 /. Tudi Shakespearova beseda nas pri Kersniku ne preseneča, kot npr.: »...biti al' ne biti«/K, PO, Č, ZD V, 193 / - tako se začenja Hamletov monolog v istoimenski tragediji.

V Kersnikovi prozi je precej verzov iz slovenske ljudske pesmi, kot npr.: »Bom šel na planince... «/K, PO, ZD V, 84 /. V JG poje pevski zbor: »Zagorske zvonove« /K, ID I, 177 /. Pri Kersniku imamo tudi kalambure: »In nomine patre / vzemi jo na kvatre! «/Groga, R, ID IV, 201 /. - Sodnik Pavel, nekdanji adjunkt, ki je speljal Vrbanoju Ančko, postane po več letih službovanja sodnik in obsodi »beračico« Ančko z besedami: »V imenu Njega Veličanstva, presvetlega cesarja...«/K, JG, ID I, 220/.

\section{Substitucija jedrne besede ali komponente}

V prozi J. Kersnika sem našel 37 frazemov s substitucijo jedrne besede ali komponente. Navajam jih samo nekaj, kot npr.... .besed niso polagali na rešeto « /K, PZL, ZD V, 58 / - tukaj je substitucija žito. Biblijskega izvora je FE: »...beseda je konj postala...«/K, PO, ZD V, 198 /. Po SP 1962 je: beseda je meso postala. »...(kaplan Klun) bo na vse kriplje dokazoval... /K, PO, ZD V, 24 /. Po SP 2001 pomeni zelo, po slovarju SP 1962: na vse kriplje si prizadevati. »...ta dva bi pa zvedela, kaj so kozje molitvice... «/K, PO, ZD V, 37 /. Po slovarju SP 2001: naučiti koga kozjih molitvic, šalj. - v tem primeru gre za glagol učiti /naučiti in substituiran biti. V veseloigri BN reče Kratki: »Saj ne sedite na ušesih«/K, ZD IV, 184 / - SP 2001: sedeti na grbi. »Ta definicija ni zrastla na Pajkovem vrtu... «/K, PO, Stricu v Ameriko, ID II, 328 / - SSKJ: to ni zrastlo na njegovem zelniku, ekspr. »Klopotal je z zobmi od razburjenosti«/K, RV, ZD III, 208 /, zastar., danes bi rekli: šklepetal.

\section{Eliptični frazemi}

Teh frazemov ni veliko. Za ilustracijo navajam: »Pogledal je po svoji navadi še nekolikokrat skozi okno, premeril sobo...«/K, RV, ZD III, 260 / - izpuščeno je: z očmi. V romanu Na Žerinjah ima FE elipso sam. v mn.: »...mežnar je dejal, da se bero za rajnega gospoda«/K, ZD I, 12 / - tj. črne maše.

\section{Inverzirani frazemi}

Našel sem jih pet. Dva sta v RV: »In kadar se vam vidi potrebno, poseči v časa kolo... «/K, ZD III / - ekspr. in »...kakor je sam dejal - naj bode $v \underline{\text { imenu } b o z ̌ j e m « ~}$ /K, ZD III, 201/. »Ko je bila služba božja končana...«/K, T, ZD III, 107/; enako še

9 Simon Gregorčič: Poezije, MK, Ljubljana 1964. 
v PZL, Znojilčevega Marka božja pot /K, ZD IV, 41 / in v povesti Očetov greh /K, ZD IV, $135 \%$.

\section{Frazemi v Kersnikovih pismih}

Kersnikova pisma so zbrana v VI. Knjigi Zbranih del. Besedilo je pripravil in opombe napisal akademik France Bernik. Prebral sem vsa slovenska pisma, ne obravnavam pa frazeologije v nemško napisanih pismih materi in očetu. Najprej je navedeno pismo Josipu Stritarju s primerjalnim frazemom: »Oni so se v svoje zastarane ideje že tako vgrizli, kakor klopi v kožo...«/K. Pisma, ZD VI, 9/. Okrog 130 pisem je napisal Franu Levcu. Tudi v pismih najdemo bogato frazeološko gradivo. V 1. pismu F. Levcu piše: »...če pride tisti hudičevi šolski ogleduh zopet $\mathrm{k}$ skušnji, potem bo že trda«/11 / - tu je elipsa glagola predla. V tem pismu sta še dva frazema : „Čakaj, hudič ti neumni, tako ti jih bojo še nocoj naložili na pleča... «/12 / in : »Ti boš že gotovo menil, da me še danes luna trka«/12 / - pog. in ekspr. V pismih F. Levcu je precej medmetnih FE, kot npr.: »Bog mu daj pamet $\gg / 15$ /. V 24. pismu je frazem «- vrag naj te vzeme...«/30/. V 145. pismu zakolne: »Da bi Te vrag... «/101 /. V Kersnikovih pismih so tudi frazeološki somatizmi, npr.: »Bog (mi je) dal dober nos! «/172. pismo F. Levcu, 110 /. Sentimentalnost izraža frazem: »...vesoljnega sveta gorje «/K, 4. pismo Marici Nadliškovi, 305 /. Isti korespondentki piše v 37. pismu: »Ah mnogo imam na jeziku in na vesti... «/343 / - ekspr. Frazeološki zraslek je BZ: »...denite vse na rovaš onega čuta, katerega Vam prikrivati ne morem «/21. pismo Marici Nadliškovi, 325 / - ekspr. V istem pismu pravi: - vedite, da imam neprenehoma moralnega mačka... «/325 /. Frazem imeti mačka izraža telesno počutje po pijanosti, Kersnikov pa kaže na visoko stopnjo odgovornosti. V 9. pismu M. Nadliškovi beremo: „V zadnjič sem Vas v prav dobro razdražil - kaj ne? - in potem sem se še bolj debelo zlagal«/311 /. Fonetična beseda je: »-in stavite to jedino na račun zaupanja«/1. pismo Ivanu Murniku, 293 /. Isti frazem je še v 17. pismu F. Levcu /27 /. V 40. pismu gospodični Nadliškovi sporoča: »...doma bom ostal in pisal - kritiko Gorazdovih balad in jezil se na Mahniča e tutti quanti« /346 / - ital.

\section{Statistična osvetlitev frazemov v prozi Janka Kersnika}

V Zbranih delih Janka Kersnika imamo 1911 frazemov, od tega števila je treba odšteti $62 \mathrm{FE}$, ki so izpod peresa Josipa Jurčiča v Rokovnjačih, tako da imamo število 1849 (tu velja omeniti, da ima Jurčič v enajstih poglavjih Rokovnjačev več frazemov kot J. Kersnik v nadaljnjih trinajstih). Največ jih je v povesti Rošlin in Vrjanko /150 /, po 147 v Podlistkih in Muhastih pismih, 124 v romanu Ciklamen, v Humoreskah 97, v Povestih za ljudstvo 91, v Jari gospodi 71, v Pismih 94 (49 v pismih Franu Levcu in $45 \mathrm{v}$ pismih Marici Nadliškovi), v romanu Agitator 69, v noveli Gospod Janez 79...Zajel sem tudi dramsko delo, šaloigro v enem dejanju, Berite Novice, v njej je $29 \mathrm{FE}$; v istem dramskem delu s podnaslovom Vesela igra $\mathrm{v}$ enem dejanju pa jih je le 26. Omeniti moram še povesti Testament, $v$ kateri je 47 $\mathrm{FE}$ in Očetov greh z $71 \mathrm{FE}$. Zanimivo je, da je v Jari gospodi in Očetovem grehu enako število frazemov.

Pri pisanju Rošlina in Vrjanka se je pisatelj naslonil na staro narodno epsko pesnitev Rošlin in Verjanko, prav zato v povesti prevladujejo pogovorni, ljudski 
frazemi. Ko je povest izšla, je bilo Kersniku 37 let. Vrhunec svoje pripovedne moči pa je dosegel z 42 leti. Tudi če upoštevamo število frazemov v Kersnikovem delu iz 40 let, lahko podkrepimo omenjeno trditev.

\section{Viri in literatura}

Janko Kersnik: Zbrano delo, I. knjiga (Na Žerinjah: NŽ; Lutrski ljudje: LL; Gospod Janez: GJ; Leposlovni podlistki: LP), DZS, Ljubljana 1968.

Janko Kersnik: Zbrano delo II. knjiga (Ciklamen: C; Agitator: A; Humoreske: H), DZS, Ljubljana 1965.

Janko Kersnik: ZD III. knjiga (Kmetske slike: KS; Testament: T; Rošlin in Vrjanko: RV; Jara gospoda: JG), DZS, Ljubljana 1986.

Janko Kersnik: ZD IV. knjiga (Povesti za ljudstvo: PZL; Očetov greh: OG; Berite Novice: BN; Pesmi), DZS, Ljubljana 1951.

Janko Kersnik: ZD V. knjiga (Podlistki: PO; Postna premišljevanja: PPr; Članki: Č;

Ocene: O; Dodatek; D), DZS, Ljubljana 1952, Janko Kersnik : ZD VI. knjiga (Pisma: Pismo; Dodatek: D), DZS, Ljubljana 1984. Janko Kersnik: Izbrano delo I. knjiga (Iz raztresenih listov: IRL; Kmetske slike: KS; Humoreske: H; Jara gospoda: JG; Pesmi v prozi: PVP), MK, Ljubljana 1974. Janko Kersnik: Izbrano delo II. knjiga (Iz raztresenih listov; IRL; Ciklamen: C;

Agitator: A; Podlistki: PO; Nedeljska pisma: NP; Popotna pisma: PP; S slavnostnim vlakom v Kočevje: SSVVK), MK, Ljubljana 1974.

Josip Jurčič: Izbrano delo IV. knjiga (Rokovnjači: R), MK, Ljubljana 1974.

A. P. Mordvilko, Očerki po russkoj frazeologii, Moskva 1964.

Janez Kersnik in njegov čas, Kranj 1997, Viktor Majdič, Kersnikov pogled na jezik.

Sveto pismo stare in nove zaveze, Ljubljana 1974, Luka: XXIII. Poglavje, 34. vrstica.

Sveto pismo stare in nove zaveze, Ljubljana 1974, Marko: IV. Poglavje, 8. vrstica. Etbin Bojc, Pregovori in reki na Slovenskem, DZS, Ljubljana 1980.

Simon Jenko: Izbrano delo, MK, Ljubljana 1976.

Simon Gregorčič: Poezije, MK, Ljubljana 1964.

\section{Фразеология в прозаических произведениях Янко Керсника}

Резюме

До сих пор еще никто не исследовал фразеологии в прозаических произведениях словенского писателя Янко Керсника. Минимальной фразеологической единицей является фонетическое слово, т. е. одно полнозначное, ударяемое слово, на которое наслоняются энклитики и проклитики. Так понимают фразем фразеологи Л. И. Ройзензон и акад. Антица Менац, основоположник загребской фразеологической школы. 
Более всего в Керсниковой прозе фраземов с опорным словом существительное + глагол, напр.: »Miklavž sam tudi ni črhnil besede «/Kersnik, Testament, ZD III, 84. »Ta jih bode naučil kozjih molitvic!«/Kersnik, poštar, Jara gospoda, ID I, $160 \%$

На втором месте, смотря на частотность, являются фраземы со структурой прилагательное + существительное. Эти ФЕ я зарегистрировал триста двадцать четыре, как напр.: »Žal besede ni bilo nikdar med njima«/Kersnik, Humoreske, ZD II, 262 /. Нависшую, угрозающую опасность выражает крылатое слово: »Damoklejev meč visi tudi nad trdimi glavami nas žurnalistov«/K, Postna premišljevanja, ZD V, 77 /. Между фразеологическими соматизмами наиболее часто выступают фраземы с опорным словом глаза: »с̌rne ос̌i«/K, Na Žerinjah, ZD I, 19, 35, 53.../.Экпрессивную стилистическую окраску показывает УСК: »Sprejemal je vse kakor suho zlato »/K, Humoreske, ZD II, 289 /.

Центральное положение в прозаических произведениях Янко Керсника занимают глагольные фраземы. Глагол применяется как опорное слово и становится грамматическим центром всего словосочетания, но одновременно сохраняет все, или некоторые формы спряжения. В романе Тестамент читаем: »...Topolščaka so prvič oklicali pri zgodnji maši«/K, T, ZD III, 104 /. В прозе Й. Керсника находим также архаические фраземы, напр.: »...smo se čudu čudili« /K, Dodatek, ZD V, 375 /. Многочислены УСК со структурой существительное + существительное. Связь между опорным словом и компонентами - союзная или предложная, напр.: »V nji je sicer videl. ..pogoj uspešnemu »boju za obstanek« /K, Božan, Rošlin in Vrjanko, ZD III, 188 /. Многочислены также тавтологические фразеосхемы, напр.: »V Borju je volivno gibanje rastlo od dne do dne«/K, A, ID I, 262 \%.

Jurij Emanuel Rojs

Goriška 1/a, 2000 Maribor

Jurij. Rojs@triera.net 